\title{
Enhance the Output Power of a Shaded Solar Photovoltaic Arrays with Shade Dispersion based TCT Configuration
}

\author{
V. Bala Raju*, Dr. Ch. Chengaiah \\ Department of Electrical and Electronics Engineering, Sri Venkateswara University College of \\ Engineering, Tirupati, India
}

Received April 9, 2021; Accepted April 19, 2021; Published April 22, 2021

\begin{abstract}
Partial shading has a negative impact on the performance parameters of a Solar Photovoltaic (PV) array, because it shades certain panels while leaving others un-shaded. This article focuses on modeling, comparing and performance assessment of $6 \times 6,6 \times 5$ and $5 \times 6$ size shadowed solar PV arrays under different partial shading cases in the MATLAB/ Simulink software. For this purpose, the simulation of series-parallel (SP), TotalCross-Tied (TCT) and proposed shade dispersion based TCT (SD-TCT) type of array configurations was carried out under few shading cases. The proposed SD-TCT was designed using the shades dispersion technique, which is based on a number logic approach. In this technique, in order to effectively remove the row-current mismatches in the TCT PV array configuration, the shaded and un-shaded modules in an array were re-arranged, so that the shading on modules expands across the whole array. The physical placement of the TCT array modules has been reordered in accordance with the proposed number logic pattern exclusive of altering the electrical links among the panels. The simulation results showed that the performance of the SD-TCT type was superior to that of conventional array configurations.
\end{abstract}

Keywords: PV Array; Modules; Configurations; Mismatch Losses; Power improvement; Shading Cases

\section{Introduction}

The power generated by solar photovoltaic (PV) plants varies with the temperature and irradiance of the PV module. Shades, such as shadows of surrounding trees, shifting clouds and dust deposition on modules, directly influence the cell temperature and radiation level of the PV system. In the shading conditions (SC), the power generated by the array is reduced and results in the output P-V curves to have multiple peaks i.e., LMPP (Local maximum power point) and GMPP (Global maximum power point). Several MPPT tracking methods for LMPP and GMPP of the solar PV array configurations have been proposed in the literature. One solution for reducing losses from malfunction and shading is PV array configurations. The foremost conventional PV array configuration or arrangements or structures are Parallel-Series (SP), Bridge-Linked (BL), Series (S), Honey-Comb (HC), Parallel (P), Total-Cross-Tied (TCT) type. In the literature of [1-5], a brief comparison study among S, P, SP, TCT, and 
BL structures was conducted in the MATLAB/Simulink environment. The findings suggested that the design of TCT achieves the best output power under most SCs. A further alternative is the use of dynamic reconfiguration methods such as power electronics Equalizer (PEE) type and the electric array reconfiguration (EAR) methods to remove multiple peaks of the shaded array $\mathrm{P}-\mathrm{V}$-specifications and thus increase the power produced by an array. The solution is also proposed in the literature. But more sensors, switches, and control algorithms are essential for implementing the above techniques in an enormous PV farm [6-10].

In order to overcome this limit, it is suggested to adopt different static array reconfiguration methods, such as magic-square pattern, Sudoku and optimal sudoku pattern and Futoshiki puzzle pattern [11-12] to boost the power generation in SC and rearrange the TCT configuration with $i \times j$ size array (where $i$ is no. of rows and $j$ is no. of columns). In the above techniques, the optimum location of any module is calculated based on the shadow model to minimize the shading losses, and the PV panel is relocated without modifying the electrical links. Such techniques, however, refer only to a square type of PV arrays and not to non-square arrays, i.e., $\mathrm{i} \neq \mathrm{j}$. For digit $\mathrm{i}$, which is either odd or even number, the current study suggests a novel approach based on shade dispersion (SDTCT) configuration of arrays $\mathrm{i}=\mathrm{j}$ and $\mathrm{i} \neq \mathrm{j}$. The proposed method for rearranging the row location of an $\mathrm{i} \times \mathrm{j}$ PV array is generalized in this context. In different shading conditions, a comparison is made of the SD-TCT configuration with different existing settings, including SP and TCT of an $\mathrm{i} \times \mathrm{j}(\mathrm{i}, \mathrm{j}=6$ and 5) array. In the SD-TCT structure, the modules positions only need to be changed once during installation, i.e., electrical links alteration of modules are unnecessary. Therefore, for the execution of the existing scheme in real time at a wide PV system, and it doesn't need a lot of switches, sensors, control algorithms. The proposed structure spreads the shadows across the PV array to ensure increased the array power under SC.

The rest paper is structured as modeling of a PV array, various array configurations, the methodology used in the proposed configuration, and the simulation, modeling and performance study of different size arrays.

\section{Mathematical Modeling}

\section{Modeling of Photovoltaic Array}

The PV cell transforms the light energy into electricity and increases the output voltage by the series of cells known as module or panel. The PV array is a grouping of the series $\left(\mathrm{N}_{\mathrm{S}}\right)$ and parallel $\left(\mathrm{N}_{\mathrm{P}}\right)$ connected panels, which are exposed in Figure 1.

The equations of 1,2 , and 3 are represented mathematically of a solar PV cell, module, and array [13-14], respectively.

$$
\begin{aligned}
& I_{\text {cell }}=I_{p h}-I_{0}\left[\exp \left\{\frac{q\left(V_{\text {cell }}+I_{\text {cell }} R_{\text {ser }}\right)}{K a T_{c}}\right\}-1\right]-\left[\frac{\left(V_{\text {cell }}+I_{\text {cell }} R_{\text {ser }}\right)}{R_{\text {par }}}\right] \\
& I_{m}=I_{p h}-I_{0}\left[\exp \left(\frac{q\left(V_{m}+I_{m} R_{\text {ser }}\right)}{n_{s} K a T_{c}}\right)-1\right]-\left[\frac{\left(V_{m}+I_{m} R_{\text {ser }}\right)}{R_{\text {par }}}\right] \\
& I_{a}=N_{P} . I_{p h}-N_{P} \cdot I_{0}\left[\exp \left(\frac{q\left(V_{a}+\frac{N_{S}}{N_{P}} I_{a} R_{\text {ser }}\right)}{N_{S} K a T_{c}}\right)-1\right]-\left[\frac{\left(V_{a}+\frac{N_{S}}{N_{P}} I_{a} R_{\text {ser }}\right)}{\frac{N_{S}}{N_{P}} \cdot R_{\text {Par }}}\right]
\end{aligned}
$$


where $\mathrm{V}_{\text {Cell }}$ and $\mathrm{I}_{\text {Cell }}, \mathrm{V}_{\mathrm{m}}$ and $\mathrm{I}_{\mathrm{m}}, \mathrm{V}_{\mathrm{a}}$ and $\mathrm{I}_{\mathrm{a}}$ are voltage[V] and current[A] of a solar PV cell, module and array, respectively. $\mathrm{N}_{\mathrm{S}}$ and $\mathrm{N}_{\mathrm{P}}$ are the no. of series and parallel connected modules, $\mathrm{n}_{\mathrm{s}}$ is the no. of series connection pv cells, $\mathrm{I}_{0}$ is reverse saturation current $[\mathrm{A}], \mathrm{I}_{\mathrm{Ph}}$ is the photo-generated current [A], $\mathrm{R}_{\text {ser }}$ and $\mathrm{R}_{\mathrm{Par}}$ are series and parallel

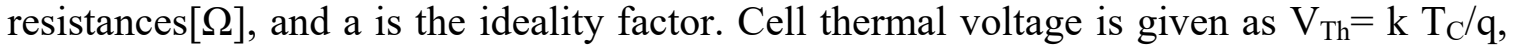
where q: Charge of electron, $\mathrm{T}_{\mathrm{C}}$ : Cell operating temp, and $\mathrm{k}$ : Boltzmann's constant.

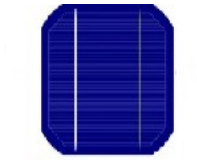

(a) PV cell

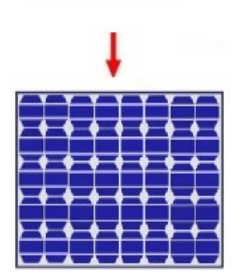

(b) Module

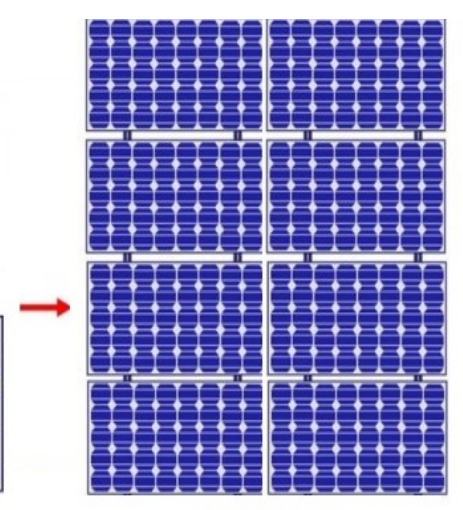

(c) Array

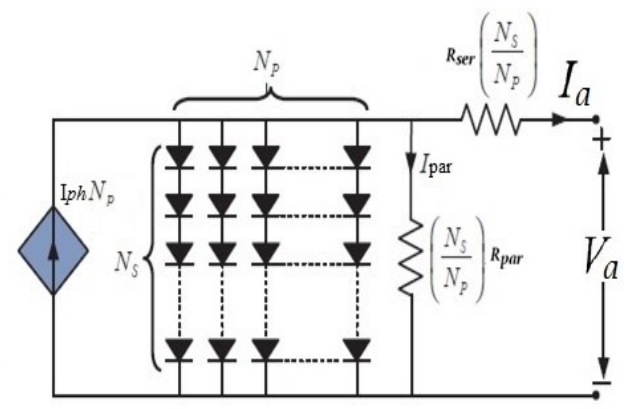

(d) Equivalent circuit

Figure 1. Solar PV array formation

\section{Modeling of Photovoltaic Array}

In this work, the Vikram Solar PV module is used for the simulation of SP, TCT, SD-TCT array arrangements. The specifications and output curves of module are shown in Figure 2.

\begin{tabular}{|lrll|}
\hline \multicolumn{1}{|c|}{ Electrical Parameters } & \multicolumn{1}{c|}{ Values } \\
\hline Maximum Power & & $270 \mathrm{~W}$ \\
Cells per module & $\mathrm{N}_{\text {cell }}$ & 72 \\
Open circuit voltage & $\mathrm{V}_{\mathrm{OC}}$ & $44 \mathrm{~V}$ \\
Short-circuit current & $\mathrm{I}_{\mathrm{SC}}$ & $8.1 \mathrm{~A}$ \\
Voltage at maximum power point & $\mathrm{V}_{\mathrm{MP}}$ & $34.7 \mathrm{~V}$ \\
Current at maximum power point & $\mathrm{I}_{\mathrm{MP}}$ & $7.8 \mathrm{~A}$ \\
Temperature coefficient of $\mathrm{V}_{\text {oc }}$ & & $-0.3583 \% /{ }^{\circ} \mathrm{C}$ \\
Temperature coefficient of $\mathrm{I}_{\mathrm{sc}}$ & & $0.0249 \% /{ }^{\circ} \mathrm{C}$ \\
Light generated current & $\mathrm{I}_{\mathrm{L}}$ & $8.1924 \mathrm{~A}$ \\
Diode saturation current & $\mathrm{I}_{\mathrm{o}}$ & $2.4871 \mathrm{e}-10$ \\
Diode ideality factor & & 0.98223 \\
Shunt resistance & $\mathrm{R}_{\mathrm{sh}}$ & $3126.5623 \Omega$ \\
Series resistance & $\mathrm{R}_{\mathrm{s}}$ & $0.52303 \Omega$ \\
\hline
\end{tabular}

(a) Vikram Solar PV module parameters

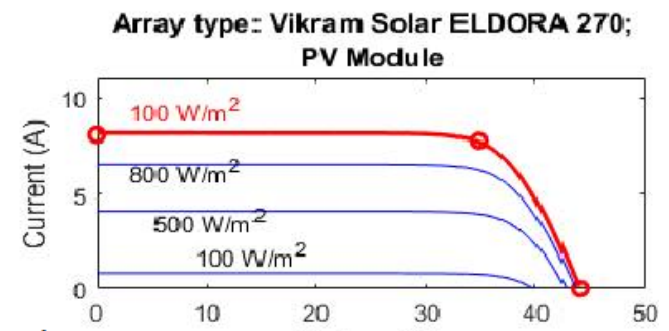

(b) I-V curves Voltage (V)

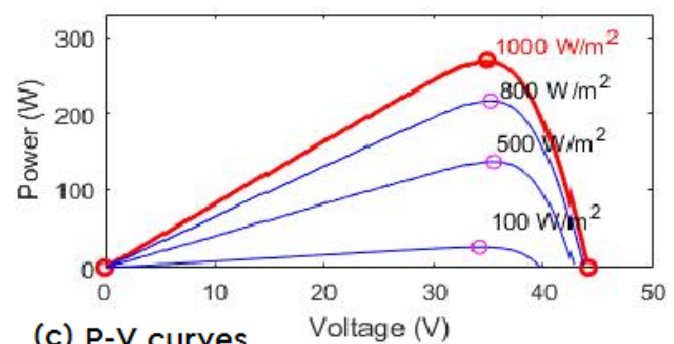

(c) P-V curves Voltage (V)

Figure 2. Parameters and output curves of a solar PV module

\section{Solar PV Array Configurations}

The foremost traditional configurations are total-cross-tied (TCT), series (S), bridge-linked (BL), series-parallel (SP), honey-comb (HC), parallel (P) type of arrangements, as illustrated in Figure 3. The difference in row currents is created because of shaded conditions, and PV panels with lower irradiation are thus bypassed. Therefore, 
many peaks are formed in the P-V output characteristics, and therefore some power is lost. PV array reconfigurations or rearrangements methods are used to spread the shade uniformly around the PV array, which can significantly reduce the mismatch losses (ML) in PV systems. Researchers have made numerous efforts to research and evaluate the shading effect on array configurations to minimize ML and to achieve maximum power production. In other words, the lower radiation PV module is relocated electrically or physically so that a single P-V peak is reached. This paper only considered SP, TCT, and proposed SD-TCT ( re-arranged TCT connection) type of configurations for analyzing the performance of different sizes PV arrays.

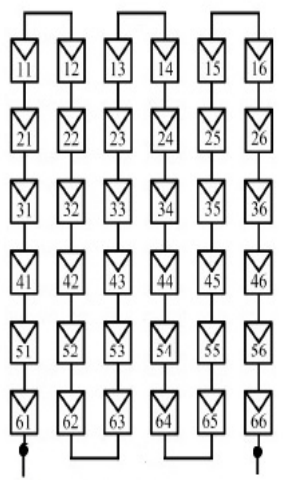

(a) $\mathrm{S}$



(b) $\mathbf{P}$

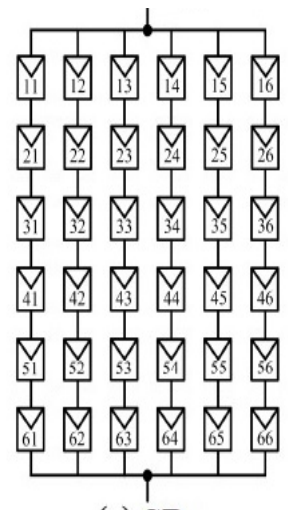

(c) SP



(d) TCT

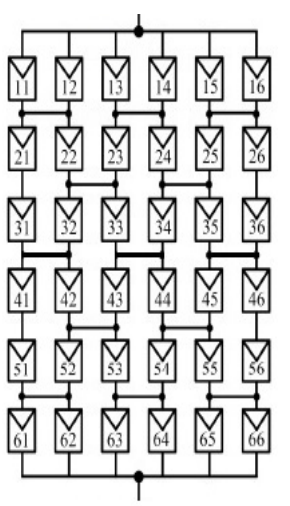

(e) BL

Figure 3. Traditional $6 \times 6$ size SPV array configurations

\section{Modeling of TCT Configuration}

The TCT (Total Cross Tied) configuration is a series-parallel version in which all rows are cross-linked to the TCT type structure. PV array's lifespan is nearly doubled by the introduction of cross-links to increase the array power. As a result of the connecting links, more loops are created. Because of this, few effects are investigated: voltage limitations in the array are found, and different currents flow throughout the same-string PV panels. In order to locate the global peak (GP) power, it is extremely important to calculate row currents in the TCT form. The current row estimate for a TCT scheme is considered to be a $6 \times 6 \mathrm{PV}$ array.

The output current in a row is the sum of the module current limits. The array currents are calculated for any TCT row by:

$$
I_{R n}=\sum_{n=1}^{6} I_{m} * S_{n}
$$

where $I_{m}$ is the PV module's maximum current at full irradiance of $1000 \mathrm{~W} / \mathrm{m}^{2}$ (STC), and $\mathrm{S}_{\mathrm{n}}=\mathrm{G}_{\mathrm{S}} / \mathrm{G}_{0}$, in which $\mathrm{G}_{\mathrm{S}}$ is the solar irradiance at shaded condition, and $\mathrm{G}_{0}$ is the $\mathrm{STC}$ irradiance. Figure 3(d) illustrates the $6 \times 6$ TCT array, and the array voltage for six rows is given by the Kirchhoff's Voltage Law (KVL) as:

$$
V_{a}=\sum_{i=1}^{6} V_{m i}
$$

where $\mathrm{V}_{\mathrm{a}}$ is the array voltage and $\mathrm{V}_{\mathrm{mi}}$ is the voltage of $\mathrm{i}^{\text {th }}$ row of the $\mathrm{PV}$ array. Applying the current law of Kirchhoff to calculate the current at each node in the TCT array and the array current is given as: 


$$
I_{a}=\sum_{j=1}^{6}\left(I_{i j}-I_{(i+1) j}\right)=0, \quad i=1,2,3,4,5,6 \quad---(6)
$$

where $\mathrm{i}$ and $\mathrm{j}$ are the number of row and column, respectively.

\section{Methodology}

\section{The General Rule for Proposed SD-TCT Array Configuration}

The proposed SD-TCT array arrangement is applicable for the shading sequence or patterns of any size, i.e., the row and column size could be odd or even number. The rule for configuring a general solar pattern can be defined as:

$n_{i j}$, Where $\left\{\begin{array}{c}i=\text { No. of rows }(i=1,2,3,4,5,6) \\ j=\text { No. of Columns }(j=1,2,3,4,5,6)\end{array}\right.$

where $n_{i j}$ is written for the $n^{\text {th }}$ element of the $i^{\text {th }}$ row and $j^{\text {th }}$ column of a shading sequence.

To determine the logic number in a column, the following equations can be considered:

$$
\begin{aligned}
& j=\left\{\begin{array}{l}
j, \quad \text { if } i=1 \\
j+(i-1) . \text { floor }\left(\frac{j_{\text {max }}}{3}\right)
\end{array}, \quad i>1\right. \\
& \text { if } j<j_{\text {max }}, \quad j=j \\
& \text { else } j=j-j_{\text {max }}
\end{aligned}
$$

If any number is repeated in a column (j), just add 1 to the corresponding column, i.e., $\mathrm{j}=\mathrm{j}+1$, otherwise take the same number in a column.

\section{Formation of Proposed SD-TCT Configuration}

An SD-TCT design aims primarily to dispatch shadows around the array under $\mathrm{SC}$ by arranging an $\mathrm{i} \times \mathrm{j}$ array column location with the numbers 1 to $\mathrm{j}$ as shown in Table 1. The proposed logic of numbers is developed for $i=$ odd and even for the column location arrangement of the $\mathrm{i} \times \mathrm{j}$ PV array. The repeating of the numbers in a specific column (C) and row (R) of a PV sequence is avoided by adding 1 to the previous logic number with the goal of obtaining a unique solution. For any array size, the proposed number logic approach is used, which is used in this paper for $6 \times 6,6 \times 5$, and $5 \times 6$ arrays.

The proposed design, therefore, reveals its pattern for puzzles and arrangements of the PV array optimized for SD-TCT (Shade dispersion based TCT configuration) arrangement in Figure 4. The 1st number in the box represents a logic number, and the 2 nd number denotes the column number. The row and column positions in a $6 \times 6$ array are arranging with the numbers 1 to 6 in the suggested arrangement, as present in Figure 4(a). Here, the first-row column location of the array contains a number in an upwards order from 1 to 6 . Numbers 1 to 6 are grouped from the second row using the proposed number logic approach, as shown in Table 1. 
Table 1. Arrangement of a $6 \times 6$ array with proposed shade dispersion number logic approach

\begin{tabular}{|c|c|c|c|c|c|c|}
\hline $\begin{array}{l}\text { Columns } \\
\text { Rows }\end{array}$ & $\mathrm{C}: 1$ & $\begin{array}{c}\mathrm{C}: 2 \\
(\mathrm{C}: 1+1)\end{array}$ & $\begin{array}{c}\mathrm{C}: 3 \\
(\mathrm{C}: 2+1)\end{array}$ & $\begin{array}{c}C: 4 \\
(C: 3+1)\end{array}$ & $\begin{array}{c}C: 5 \\
(C: 4+1)\end{array}$ & $\begin{array}{c}\text { C:6 } \\
(C: 5+1)\end{array}$ \\
\hline R:1 & 1 & 2 & 3 & 4 & 5 & 6 \\
\hline $\begin{array}{c}\mathrm{R}: 2 \\
(\mathrm{R}: 1+2)\end{array}$ & 3 & 4 & 5 & 6 & $7-6=1$ & $8-6=2$ \\
\hline $\begin{array}{c}\mathrm{R}: 3 \\
(\mathrm{R}: 2+2)\end{array}$ & 5 & 6 & $7-6=1$ & $8-6=2$ & 3 & 4 \\
\hline $\begin{array}{c}\mathrm{R}: 4 \\
(\mathrm{R}: 3+2)\end{array}$ & $\begin{array}{l}7-6=1 \\
1+1=2\end{array}$ & $\begin{array}{l}8-6=2 \\
2+1=3\end{array}$ & $3+1=4$ & $4+1=\mathbf{5}$ & $5+1=6$ & $\begin{array}{l}6+1=7 \\
7-6=1\end{array}$ \\
\hline $\begin{array}{c}\mathrm{R}: 5 \\
(\mathrm{R}: 4+2)\end{array}$ & 4 & 5 & 6 & $7-6=1$ & $8-6=2$ & 3 \\
\hline $\begin{array}{c}\text { R:6 } \\
(\mathrm{R}: 5+2)\end{array}$ & 6 & $7-6=1$ & $8-6=2$ & 3 & 4 & 5 \\
\hline
\end{tabular}

Table 2. Arrangement of a $6 \times 5$ array with proposed shade dispersion number logic approach

\begin{tabular}{|c|c|c|c|c|c|}
\hline Columns & C:1 & $\begin{array}{c}\mathrm{C}: 2 \\
(\mathrm{C}: 1+1)\end{array}$ & $\begin{array}{c}\mathrm{C}: 3 \\
(\mathrm{C}: 2+1)\end{array}$ & $\begin{array}{c}\mathrm{C}: 4 \\
(\mathrm{C}: 3+1)\end{array}$ & $\begin{array}{c}C: 5 \\
(C: 4+1)\end{array}$ \\
\hline R:1 & 1 & 2 & 3 & 4 & 5 \\
\hline $\begin{array}{c}\mathrm{R}: 2 \\
(\mathrm{R}: 1+2)\end{array}$ & 3 & 4 & 5 & 6 & $7-6=1$ \\
\hline $\begin{array}{c}\mathbf{R}: 3 \\
(\mathrm{R}: 2+2)\end{array}$ & 5 & 6 & $7-6=1$ & $8-6=2$ & 3 \\
\hline $\begin{array}{c}\mathrm{R}: 4 \\
(\mathrm{R}: 3+2)\end{array}$ & $\begin{array}{l}7-6=1 \\
1+1=2\end{array}$ & $\begin{array}{l}8-6=2 \\
2+1=3\end{array}$ & $3+1=4$ & $4+1=\mathbf{5}$ & $5+1=6$ \\
\hline $\begin{array}{c}\text { R:5 } \\
(\mathrm{R}: 4+2)\end{array}$ & 4 & 5 & 6 & $7-6=1$ & $8-6=2$ \\
\hline $\begin{array}{c}\text { R:6 } \\
(R: 5+2)\end{array}$ & 6 & $7-6=1$ & $8-6=2$ & 3 & 4 \\
\hline
\end{tabular}


Table 3. Arrangement of a $5 \times 6$ array with proposed shade dispersion number logic approach

\begin{tabular}{|c|c|c|c|c|c|c|}
\hline $\begin{array}{l}\text { Columns } \\
\text { Rows }\end{array}$ & C:1 & $\begin{array}{c}\text { C:2 } \\
(C: 1+1)\end{array}$ & $\begin{array}{c}\mathrm{C}: 3 \\
(\mathrm{C}: 2+1)\end{array}$ & $\begin{array}{c}\mathrm{C}: 4 \\
(\mathrm{C}: 3+1)\end{array}$ & $\begin{array}{c}\text { C:5 } \\
(C: 4+1)\end{array}$ & $\begin{array}{c}\text { C:6 } \\
(\mathrm{C}: 5+1)\end{array}$ \\
\hline R:1 & 1 & 2 & 3 & 4 & 5 & $\begin{array}{l}6 \\
6-5=1\end{array}$ \\
\hline $\begin{array}{c}\mathrm{R}: 2 \\
(\mathrm{R}: 1+2)\end{array}$ & 3 & 4 & 5 & $\begin{array}{l}6 \\
6-5=1\end{array}$ & 2 & 3 \\
\hline $\begin{array}{c}\mathrm{R}: 3 \\
(\mathrm{R}: 2+2)\end{array}$ & 5 & $\begin{array}{l}6 \\
6-5=1\end{array}$ & 2 & 3 & 4 & 5 \\
\hline $\begin{array}{c}\text { R:4 } \\
(R: 3+2)\end{array}$ & $7-5=2$ & 3 & 4 & 5 & $\begin{array}{l}6 \\
6-5=\quad 1\end{array}$ & 2 \\
\hline $\begin{array}{c}\text { R:5 } \\
(R: 4+2)\end{array}$ & 4 & 5 & $\begin{array}{l}6 \\
6-5=1\end{array}$ & 2 & 3 & 4 \\
\hline
\end{tabular}

\begin{tabular}{|l|l|l|l|l|l|}
\hline 11 & 22 & 33 & 44 & 55 & 66 \\
\hline 31 & 42 & 53 & 64 & 15 & 26 \\
\hline 51 & 62 & 13 & 24 & 35 & 46 \\
\hline 21 & 32 & 43 & 54 & 65 & 16 \\
\hline 41 & 52 & 63 & 14 & 25 & 36 \\
\hline 61 & 12 & 23 & 34 & 45 & 56 \\
\hline
\end{tabular}

(a) $6 \times 6$ SD-TCT

\begin{tabular}{|l|l|l|l|l|}
\hline 11 & 22 & 33 & 44 & 55 \\
\hline 31 & 42 & 53 & 64 & 15 \\
\hline 51 & 62 & 13 & 24 & 35 \\
\hline 21 & 32 & 43 & 54 & 65 \\
\hline 41 & 52 & 63 & 14 & 25 \\
\hline 61 & 12 & 23 & 34 & 45 \\
\hline
\end{tabular}

(b) $6 \times 5$ SD-TCT

\begin{tabular}{|l|l|l|l|l|l|}
\hline 11 & 22 & 33 & 44 & 55 & 16 \\
\hline 31 & 42 & 53 & 14 & 25 & 36 \\
\hline 51 & 12 & 23 & 34 & 45 & 56 \\
\hline 21 & 32 & 43 & 54 & 15 & 26 \\
\hline 41 & 52 & 13 & 24 & 35 & 46 \\
\hline
\end{tabular}

(c) $5 \times 6$ SD-TCT

Figure 4. Arrangement of $6 \times 6,6 \times 5$ and $5 \times 6$ arrays with proposed number logic approach

\section{Re-arrangement of Array Modules in TCT Configuration}

Reconfiguration methods are used to spread the partial shade effect with every conventional configuration. Several literature attempts are made to establish the best scheme for PV systems for all operating conditions in order to find the best configuration [15-16]. TCT is now the most feasible interconnections scheme for achieving efficient and sustainable photovoltaic power generation based on crucial evaluations with TCT, BL, and SP. Some scholarly studies for PV array reconfiguration that adopts TCT interconnect are available in the literature. A smart reconfiguration approach is mandatory to define the new positions in a TCT PV array. A new physical shade dispersion device based on the logic number is thus proposed for this work. The method follows the column wise relocation process in order to rearrange the TCT array, which allows shades with a minimum row current difference to be dispersed. The methodology opted for rearrangement of array modules in TCT with a number logic approach, as described in the previous section. The formation of $6 \times 6,6 \times 5$ and $5 \times 6$ array configurations with shade dispersion by logic number approach is illustrated in Figure 5(c), 5(d) and 5(e), respectively. 


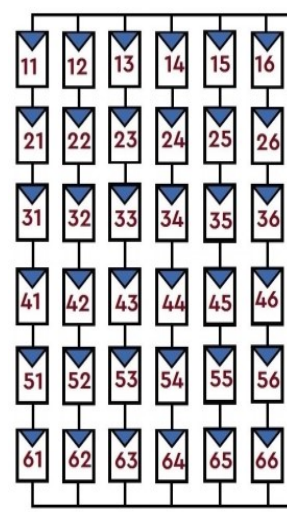

(a) $6 \times 6 \mathrm{~S}-\mathrm{P}$

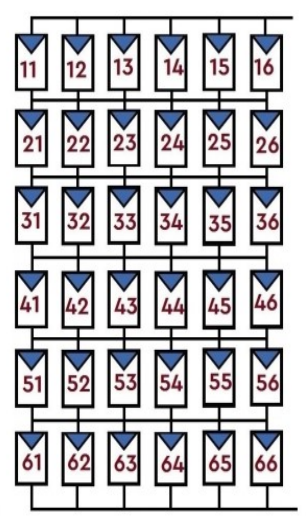

(b) $6 \times 6 \mathrm{~T}-\mathrm{C}-\mathrm{T}$



(c) 6x6 Proposed SD-TCT

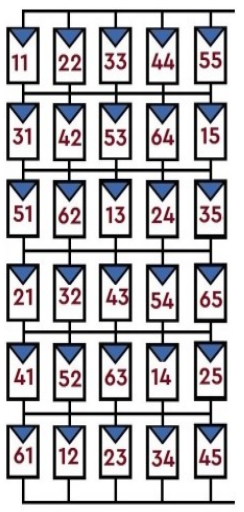

(d) $6 \times 5$ Proposed SD-TCT

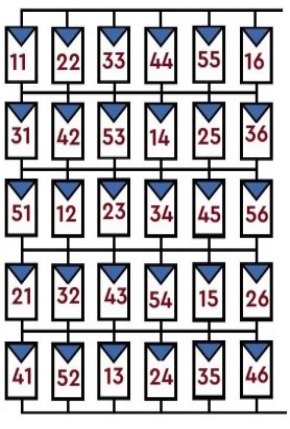

(e) $5 \times 6$ Proposed SD-TCT

Figure 5. (a)-(b): S-P and TCT, (c)-(e): Re-arrangements of TCT array (SD-TCT)

\section{Physical Relocation of Modules in the Proposed Configuration}

The most difficult problem of this procedure was to pick the efficient reconfigurable sequence to spread the shading through the array. The first digit is the logical number in each box in the proposed SD-TCT arrangement, and the 2nd digit indicates the column. This method has the lead of matching the numbers 1 to 6 without repeating them. The purpose of this model system is to share out shadow effects without altering electrical connections by modifying their physical location of PV modules. This means that the panel number 34 is at a third row-fourth column in TCT. But in SD-TCT format, it moves physically into 4th column in the 6th row, as shown in Figure 6(c). Different improvements are made to all PV panels, which increase the current in an entry node and decrease the circumvention of the array modules. This increases the array of power efficiency. Figures 6(b)-6(c) demonstrate the reorganization of array modules by the use of the proposed arrangement without modifying the electrical links to the panels in the shading cases.

\begin{tabular}{|l|l|l|l|l|l|}
\hline 11 & 12 & 13 & 14 & 15 & 16 \\
\hline 21 & 22 & 23 & 24 & 25 & 26 \\
\hline 31 & 32 & 33 & 34 & 35 & 36 \\
\hline 41 & 42 & 43 & 44 & 45 & 46 \\
\hline 51 & 52 & 53 & 54 & 55 & 56 \\
\hline 61 & 62 & 63 & 64 & 65 & 66 \\
\hline
\end{tabular}

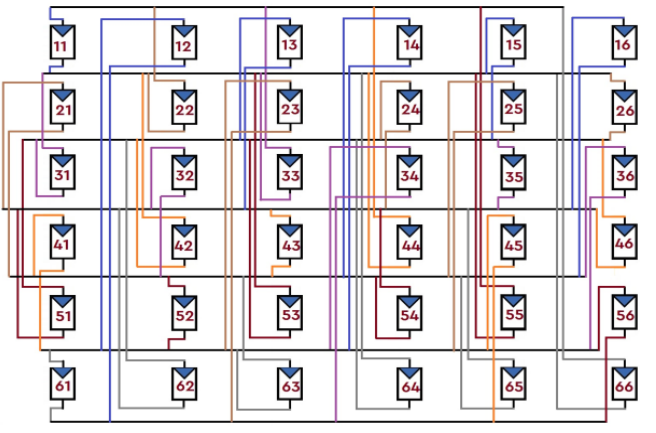

(c) Proposed SD-TCT Configuration arrangement (b) Proposed SD-TCT Configuration pattern

\begin{tabular}{|l|l|l|l|l|l|}
\hline 11 & 22 & 33 & 44 & 55 & 66 \\
\hline 31 & 42 & 53 & 64 & 15 & 26 \\
\hline 51 & 62 & 13 & 24 & 35 & 46 \\
\hline 21 & 32 & 43 & 54 & 65 & 16 \\
\hline 41 & 52 & 63 & 14 & 25 & 36 \\
\hline 61 & 12 & 23 & 34 & 45 & 56 \\
\hline
\end{tabular}

rangement of proposed $6 \times 6$ SD-TCT array configuration

\section{Analysis of Shading Patterns}

Solar PV modules in the array are partly shaded by shadows in surrounding trees, moveable clouds, sand, or dust deposition of the panels. In this paper, shading cases are considered for performance analysis illustrated in Figures 7(a), 9(a), 10(a), and corresponding shade dispersions in SD-TCT configuration are shown in Figures 7(b), 9(b), 10(b), respectively. Each shaded module receives a solar irradiance of $500 \mathrm{~W} / \mathrm{m}^{2}$, and the maximum irradiance of un-shaded modules is $1000 \mathrm{~W} / \mathrm{m}^{2}$. 


\section{Shading Cases for a $6 \times 6$ Array}

The shading cases considered for analyzing the shade dispersion in SD-TCT configuration of a $6 \times 6 \mathrm{SPV}$ array is illustrated in Figure 7. Figure 7(a) represents the shading pattern in TCT array connection and Figure 7(b) represents the shade dispersion in SD-TCT arrangement with number logic approach as explained in the previous section. The proposed method disperses the shades on PV module with in a column only. So, in the complete column shading cases, there is no shade dispersion occurs as shown in case-7: single column shading, and case-9: two column shading of a $6 \times 6$ array. In non-shading case (i.e., case-U), all 36 modules in a $6 \times 6 \mathrm{PV}$ array receives full irradiance at STC of $1000 \mathrm{~W} / \mathrm{m}^{2}$.

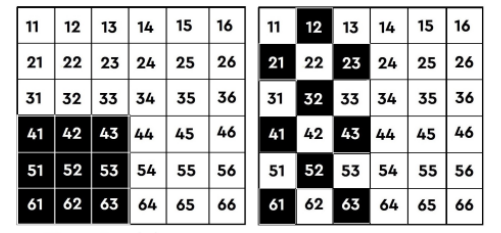

(b)

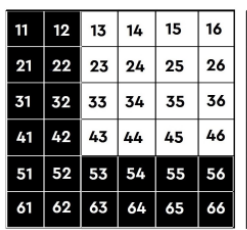

Case-4 (a)

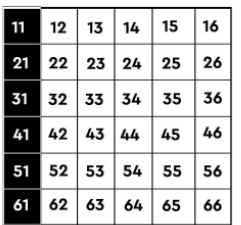

Case- 7 (a)
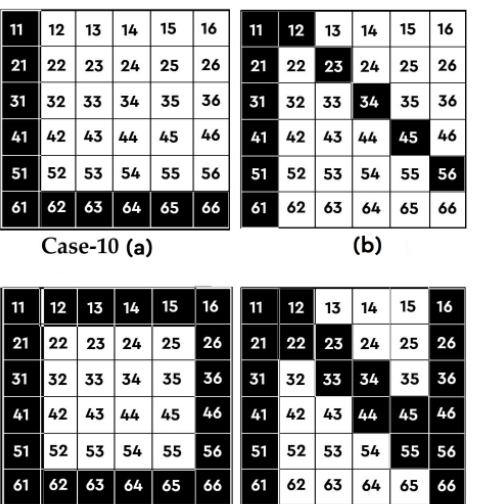

Case-13 (a)

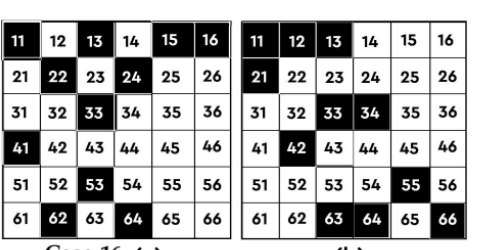

(b)

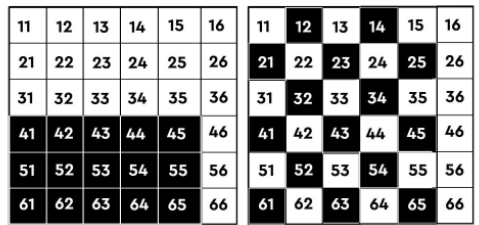

(b)

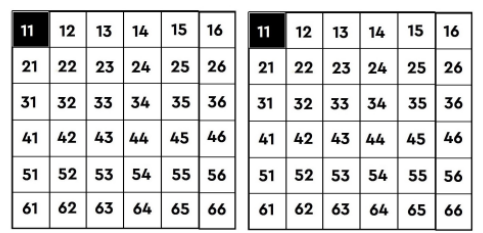

(b)

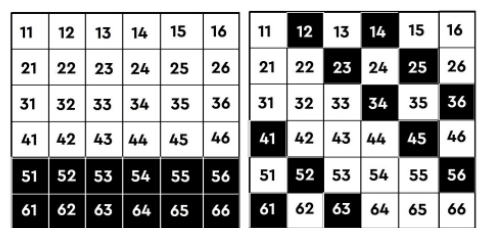

Case-8 (a)

(b)

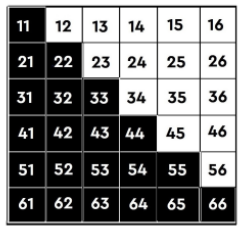

Case-11 (a)
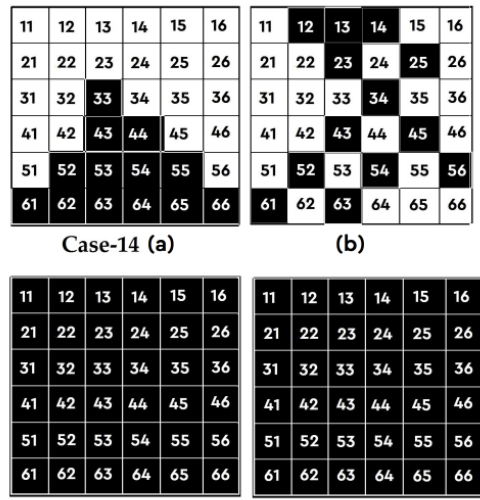

Case-17 (a)

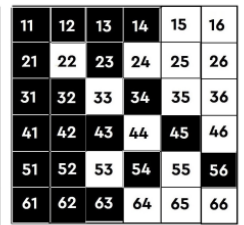

(b)

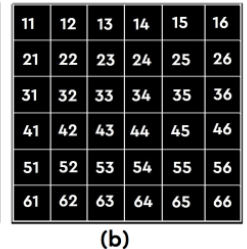

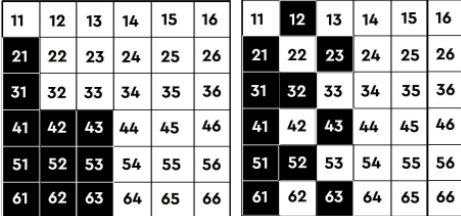

(b)


Case-9 (a)



(b)

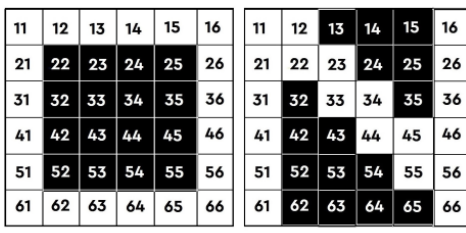

Case-12 (a)

(b)
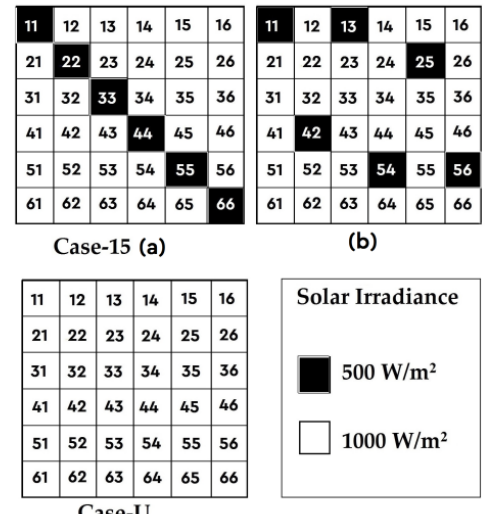

Solar Irradiance

$500 \mathrm{~W} / \mathrm{m}^{2}$

$1000 \mathrm{~W} / \mathrm{m}^{2}$

Figure 7. Shade dispersion analysis in a $6 \times 6$ array under various shadings:

(a) TCT (b) SD-TCT configuration 


\section{Shade Dispersion in SD-TCT under Shading Case- 1 of a $6 \times 6$ Array}

Any shade extends across the whole array in the proposed SD-TCT system to ensure a maximum current for every node. The shaded row modules are spread over various rows when a shade occurs over a full row, so the current entering every row is almost equal to maximum. Figure 8 explains the dispersion of the shade in the 6th-row partial shading arrangement of TCT and SD-TCT.

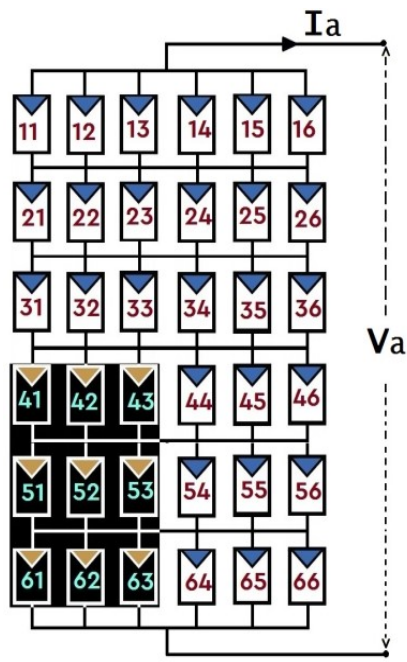

(a) TCT Arrangement

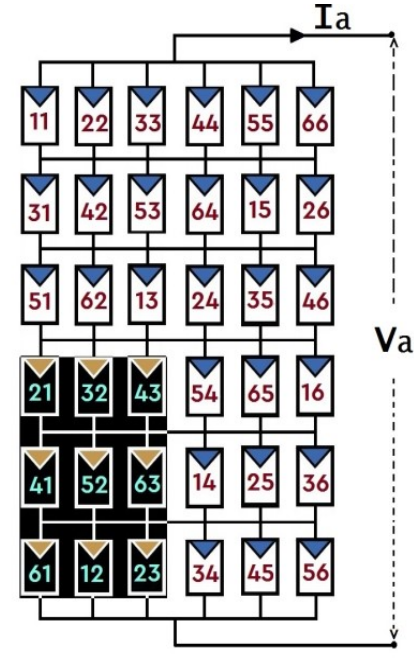

(b) SD-TCT Arrangement

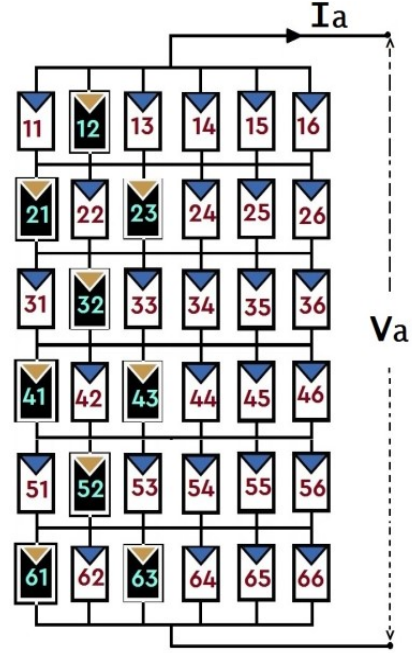

(c) Shade dispersion in SD-TCT

Figure 8. Shade dispersion in SD-TCT configuration for a $6 \times 6$ array under 1 st shading case

\section{Row Current Estimation}

The current in rows assessment shows clear shade in the array arrangements. Moreover, by shifting the row currents, the severity of the shade can be understood clearly. The procedure for row current estimation for a $6 \times 6$ TCT under a short narrow shade sequence is given in Figure 8(a) as fallows (illustrated in Figure 7: case-1 (a) ).

\section{Row Current Estimation in a $6 \times 6$ TCT Configuration under Case- 1 :}

The generated current is expressed in equation-(7) in a $6 \times 6 \mathrm{PV}$ array depends on the solar irradiance,

$$
I_{R i}=\sum_{n=1}^{6} S_{M n} I_{m}=S_{M 1} I_{m}+S_{M 2} I_{m}+S_{M 3} I_{m}+S_{M 4} I_{m}+S_{M 5} I_{m}+S_{M 6} I_{m}
$$

where $S_{M n}$ is the shading factor of the $\mathrm{n}^{\text {th }} \mathrm{PV}$ module in an array.

$$
S_{M 1}=\left(\frac{G_{M 1}}{G_{S T C}}\right), S_{M 2}=\left(\frac{G_{M 2}}{G_{S T C}}\right), S_{M 3}=\left(\frac{G_{M 3}}{G_{S T C}}\right), S_{M 4}=\left(\frac{G_{M 4}}{G_{S T C}}\right), S_{M 5}=\left(\frac{G_{M 5}}{G_{S T C}}\right), S_{M 6}=\left(\frac{G_{M 6}}{G_{S T C}}\right)
$$

where $I_{R i}$ is the row current of the $\mathrm{i}^{\text {th }}$ row. $\mathrm{I}_{\mathrm{m}}$ is the PV module's maximum current, $\mathrm{G}_{\mathrm{SMn}}$ is solar irradiance at the shaded condition, and $\mathrm{G}_{\mathrm{STC}}$ is irradiance at STC, i.e., 1000 $\mathrm{W} / \mathrm{m}^{2}$.

The row current of the first, second, third, fourth, fifth, and sixth rows of the TCT arrangements is evaluated as given by:

$$
I_{R 1}=\left(6 \times\left(\frac{1000}{1000}\right) \times I_{m}\right)=6 I_{m}=I_{R 2}=I_{R 3}
$$


In $1^{\text {st }}, 2^{\text {nd }}$ and $3^{\text {rd }}$ rows, all six modules receive full irradiance of $1000 \mathrm{w} / \mathrm{m}^{2}$. In 4 th, 5 th and 6th rows, the irradiance of three modules is $500 \mathrm{~W} / \mathrm{m}^{2}$, and other three modules have $1000 \mathrm{~W} / \mathrm{m}^{2}$, as shown in Figure 6(a).

$$
I_{R 4}=\left(3 \times\left(\frac{1000}{1000}\right) \times I_{m}\right)+\left(3 \times\left(\frac{500}{1000}\right) \times I_{m}\right)=\left(3 \times 1 \times I_{m}\right)+\left(3 \times 0.5 \times I_{m}\right)=4.5 I_{m}=I_{R 5}=I_{R 6}
$$

Row Current Estimation in a $6 \times 6$ Proposed SD-TCT Configuration under Case-1

Compared to the TCT model, a row current assessment was also done by the number logic approach proposed. The row current for the first to the sixth row is set in the following sequence (from Figure 8(c)):

$1^{\text {st }}$ row: $I_{R 1}=\left(1 \times 0.5 \times I_{m}\right)+\left(5 \times 1 \times I_{m}\right)=5.5 I_{m}$

$2^{\text {nd }}$ row: $I_{R 2}=\left(2 \times 0.5 \times I_{m}\right)+\left(4 \times 1 \times I_{m}\right)=5 I_{m}$

$3^{\text {rd }}$ row: $I_{R 3}=\left(1 \times 0.5 \times I_{m}\right)+\left(5 \times 1 \times I_{m}\right)=5.5 I_{m}$

$4^{\text {th }}$ row: $I_{R 4}=\left(2 \times 0.5 \times I_{m}\right)+\left(4 \times 1 \times I_{m}\right)=5 I_{m}$

$5^{\text {th }}$ row: $I_{R 5}=\left(1 \times 0.5 \times I_{m}\right)+\left(5 \times 1 \times I_{m}\right)=5.5 I_{m}$

$6^{\text {th }}$ row: $I_{R 6}=\left(2 \times 0.5 \times I_{m}\right)+\left(4 \times 1 \times I_{m}\right)=5 I_{m}$

Row Current Estimation in a $6 \times 6$ Proposed SD-TCT Configuration under Cases -1 to 17:

Similarly by using the equation-(7), the row currents in a $6 \times 6,6 \times 5$ and $5 \times 6$ arrays are calculated under proposed 17 different shading cases (illustrated in Figures-7, 9 and 10). The calculated theoretical values of voltage, current and power for a $6 \times 6$ array TCT and SD-TCT configuration are tabulated in Table 4. In Table 4, IR is the PV modules row current that is gradually being bypassed.

Table 4. Theoretical calculations of V, I and P for a $6 \times 6$ array TCT and SD-TCT configurations

\begin{tabular}{|c|c|c|c|c|c|c|c|}
\hline \multicolumn{3}{|c|}{ TCT Configuration } & \multicolumn{3}{|c|}{ SD-TCT Configuration } & \multirow[b]{2}{*}{$\begin{array}{l}\text { Highest } \\
\text { power: } \\
P \\
\left(\times \mathrm{V}_{\mathrm{m}} \mathrm{I}_{\mathrm{m}}\right)\end{array}$} & \multirow[b]{2}{*}{$\begin{array}{c}\text { Best } \\
\text { Configuration }\end{array}$} \\
\hline $\begin{array}{c}\text { Row } \\
\text { maximum } \\
\text { currents: } I_{R} \\
\left(\times \mathrm{I}_{\mathrm{m}}\right) \\
\end{array}$ & $\begin{array}{c}\text { Available } \\
\text { Voltage: } \\
\text { V } \\
\left(\times V_{\mathrm{m}}\right) \\
\end{array}$ & $\begin{array}{c}\text { Power: } \\
\quad P \\
\left(\times V_{m} I_{m}\right) \\
\end{array}$ & $\begin{array}{c}\text { Row } \\
\text { maximum } \\
\text { currents: } \mathrm{I}_{\mathrm{R}} \\
\left(\times \mathrm{I}_{\mathrm{m}}\right) \\
\end{array}$ & $\begin{array}{c}\text { Available } \\
\text { Voltage: } \\
\text { V } \\
\left(\times V_{\mathrm{m}}\right) \\
\end{array}$ & $\begin{array}{c}\text { Power: } \\
\quad \mathrm{P} \\
\left(\times \mathrm{V}_{\mathrm{m}} \mathrm{I}_{\mathrm{m}}\right) \\
\end{array}$ & & \\
\hline \multicolumn{8}{|l|}{$\underline{\text { Case-U }}$} \\
\hline $\mathrm{I}_{\mathrm{R} 1}=6$ & 6 & 36 & $\mathrm{I}_{\mathrm{R} 1}=6$ & 6 & 36 & & \\
\hline $\mathrm{I}_{\mathrm{R} 2}=6$ & 5 & 30 & $\mathrm{I}_{\mathrm{R} 2}=6$ & 5 & 30 & & \\
\hline $\mathrm{I}_{\mathrm{R} 3}=6$ & 4 & 24 & $\mathrm{I}_{\mathrm{R} 3}=6$ & 4 & 24 & 36 & TCT/ \\
\hline$I_{R 4}=6$ & 3 & 18 & $\mathrm{I}_{\mathrm{R} 4}=6$ & 3 & 18 & & SD-TCT \\
\hline $\mathrm{I}_{\mathrm{RS}}=6$ & 2 & 12 & $\mathrm{I}_{\mathrm{RS} S}=6$ & 2 & 12 & & \\
\hline $\mathrm{I}_{\mathrm{R} 6}=6$ & 1 & 6 & $\mathrm{I}_{\mathrm{R} 6}=6$ & 1 & 6 & & \\
\hline \multicolumn{8}{|l|}{ Case-1 } \\
\hline $\mathrm{I}_{\mathrm{R} 6}=4.5$ & 6 & 27 & $\mathrm{I}_{\mathrm{R} 6}=5$ & 6 & 30 & & \\
\hline $\mathrm{I}_{\mathrm{R} 5}=4.5$ & 5 & 22.5 & $\mathrm{I}_{\mathrm{R} 4}=5$ & 5 & 25 & & \\
\hline $\mathrm{I}_{\mathrm{R} 4}=4.5$ & 4 & 18 & $\mathrm{I}_{\mathrm{R} 2}=5$ & 4 & 20 & 30 & \\
\hline $\mathrm{I}_{\mathrm{R} 3}=6$ & 3 & 18 & $\mathrm{I}_{\mathrm{R} 5}=5.5$ & 3 & 16.5 & & SD-TCT \\
\hline$I_{R 2}=6$ & 2 & 12 & $\mathrm{I}_{\mathrm{R} 3}=5.5$ & 2 & 11 & & \\
\hline $\mathrm{I}_{\mathrm{R} 1}=6$ & 1 & 6 & $\mathrm{I}_{\mathrm{R} 1}=5.5$ & 1 & 5.5 & & \\
\hline
\end{tabular}


Case-2

\begin{tabular}{|c|c|c|c|c|c|c|c|}
\hline $\mathrm{I}_{\mathrm{R} 6}=3.5$ & 6 & 21 & $\mathrm{I}_{\mathrm{R} 6}=4.5$ & 6 & 27 & & \\
\hline $\mathrm{I}_{\mathrm{R} 5}=3.5$ & 5 & 17.5 & $\mathrm{I}_{\mathrm{R} 4}=4.5$ & 5 & 22.5 & & \\
\hline $\mathrm{I}_{\mathrm{R} 4}=3.5$ & 4 & 14 & $\mathrm{I}_{\mathrm{R} 2}=4.5$ & 4 & 18 & 27 & SD-TCT \\
\hline $\mathrm{I}_{\mathrm{R} 3}=6$ & 3 & 18 & $\mathrm{I}_{\mathrm{R} 5}=5$ & 3 & 15 & & \\
\hline $\mathrm{I}_{\mathrm{R} 2}=6$ & 2 & 12 & $\mathrm{I}_{\mathrm{R} 3}=5$ & 2 & 10 & & \\
\hline $\mathrm{I}_{\mathrm{R} 1}=6$ & 1 & 6 & $\mathrm{I}_{\mathrm{R} 1}=5$ & 1 & 5 & & \\
\hline
\end{tabular}

Case-3

$\mathrm{I}_{\mathrm{R} 5}=4.5$

$\mathrm{I}_{\mathrm{R} 4}=4.5$

$\mathrm{I}_{\mathrm{R} 3}=5.5$

$\mathrm{I}_{\mathrm{R} 2}=5.5$

$\mathrm{I}_{\mathrm{R} 1}=6$

$\begin{array}{ll}27 & \mathrm{I}_{\mathrm{R} 6}=5 \\ 22.5 & \mathrm{I}_{\mathrm{R} 5}=5 \\ 18 & \mathrm{I}_{\mathrm{R} 4}=5 \\ 16.5 & \mathrm{I}_{\mathrm{R} 3}=5 \\ 11 & \mathrm{I}_{\mathrm{R} 2}=5 \\ 6 & \mathrm{I}_{\mathrm{R} 1}=5.5\end{array}$

30

6

4

2

$\underline{\text { Case-4 }}$

$\mathrm{I}_{\mathrm{R} 6}=3$

$\mathrm{I}_{\mathrm{R} 5}=3$

$\mathrm{I}_{\mathrm{R} 4}=5$

$\mathrm{I}_{\mathrm{R} 3}=5$

$\mathrm{I}_{\mathrm{R} 2}=5$

$\mathrm{I}_{\mathrm{R} 1}=5$

Case-5

$\mathrm{I}_{\mathrm{R} 1}=5.5$
$\mathrm{I}_{\mathrm{R} 2}=6$
$\mathrm{I}_{\mathrm{R} 3}=6$
$\mathrm{I}_{\mathrm{R} 4}=6$
$\mathrm{I}_{\mathrm{R} 5}=6$
$\mathrm{I}_{\mathrm{R} 6}=6$

6
5
4
3
2
1

$\begin{array}{ll}33 & \mathrm{I}_{\mathrm{R} 1}=5.5 \\ 30 & \mathrm{I}_{\mathrm{R} 2}=6 \\ 24 & \mathrm{I}_{\mathrm{R} 3}=6 \\ 18 & \mathrm{I}_{\mathrm{R} 4}=6 \\ 12 & \mathrm{I}_{\mathrm{R} 5}=6 \\ 6 & \mathrm{I}_{\mathrm{R} 6}=6\end{array}$

$\mathrm{I}_{\mathrm{R} 3}=4$

$\mathrm{I}_{\mathrm{R} 2}=4$

$\mathrm{I}_{\mathrm{R} 1}=4.5$

$\mathrm{I}_{\mathrm{R} 6}=4.5$

$\mathrm{I}_{\mathrm{R} 5}=4.5$

$\mathrm{I}_{\mathrm{R} 4}=4.5$

$\begin{array}{ll}6 & 30 \\ 5 & 25 \\ 4 & 20 \\ 3 & 15 \\ 2 & 10 \\ 1 & 5.5\end{array}$

30

SD-TCT

Case-6

$\mathrm{I}_{\mathrm{R} 6}=3$
$\mathrm{I}_{\mathrm{R} 5}=6$
$\mathrm{I}_{\mathrm{R} 4}=6$
$\mathrm{I}_{\mathrm{R} 3}=6$
$\mathrm{I}_{\mathrm{R} 2}=6$
$\mathrm{I}_{\mathrm{R} 1}=6$

18

18
30
24
18
12
6

$\mathrm{I}_{\mathrm{R} 6}=5.5$

$\mathrm{I}_{\mathrm{R} 5}=5.5$

$\mathrm{I}_{\mathrm{R} 4}=5.5$

$\mathrm{I}_{\mathrm{R} 3}=5.5$

$\mathrm{I}_{\mathrm{R} 2}=5.5$

$\mathrm{I}_{\mathrm{R} 1}=5.5$
$\begin{array}{ll}6 & 24\end{array}$

$4 \quad 18$ 18
13.5
9 4.5

24

SD-TCT

Case-7

$\begin{array}{llllll}\mathrm{I}_{\mathrm{R} 6}=5.5 & 6 & 33 & \mathrm{I}_{\mathrm{R} 6}=5.5 & 6 & 33 \\ \mathrm{I}_{\mathrm{R} 5}=5.5 & 5 & 27.5 & \mathrm{I}_{\mathrm{R} 5}=5.5 & 5 & 27.5 \\ \mathrm{I}_{\mathrm{R} 4}=5.5 & 4 & 22 & \mathrm{I}_{\mathrm{R} 4}=5.5 & 4 & 22 \\ \mathrm{I}_{\mathrm{R} 3}=5.5 & 3 & 16.5 & \mathrm{I}_{\mathrm{R} 3}=5.5 & 3 & 16.5 \\ \mathrm{I}_{\mathrm{R} 2}=5.5 & 2 & 11 & \mathrm{I}_{\mathrm{R} 2}=5.5 & 2 & 11 \\ \mathrm{I}_{\mathrm{R} 1}=5.5 & 1 & 5.5 & \mathrm{I}_{\mathrm{R} 1}=5.5 & 1 & 5.5\end{array}$

33

TCT/

$16.5 \quad 33 \quad$ SD-TCT

Case-8

$\mathrm{I}_{\mathrm{R} 6}=3$

$\mathrm{I}_{\mathrm{R} 5}=3$
$\mathrm{I}_{\mathrm{R} 4}=6$

$\mathrm{I}_{\mathrm{R} 3}=6$
$\mathrm{I}_{\mathrm{R} 2}=6$

$\mathrm{I}_{\mathrm{R} 1}=6$

6
5
4
3
2
1

$\begin{array}{ll}18 & \mathrm{I}_{\mathrm{R} 6}=5 \\ 15 & \mathrm{I}_{\mathrm{R} 5}=5 \\ 24 & \mathrm{I}_{\mathrm{R} 4}=5 \\ 18 & \mathrm{I}_{\mathrm{R} 3}=5 \\ 12 & \mathrm{I}_{\mathrm{R} 2}=5 \\ 6 & \mathrm{I}_{\mathrm{R} 1}=5\end{array}$

$\mathrm{I}_{\mathrm{R} 6}=5$

$\mathrm{I}_{\mathrm{R} 5}=5$

$\mathrm{I}_{\mathrm{R} 3}=5$

$\mathrm{I}_{\mathrm{R} 1}=5$

5.5

33

SD-TCT

Case-9

$\mathrm{I}_{\mathrm{R} 6}=5$
$\mathrm{I}_{\mathrm{R} 5}=5$
$\mathrm{I}_{\mathrm{R} 4}=5$

$\begin{array}{ll}30 & \mathrm{I}_{\mathrm{R} 6}=5 \\ 25 & \mathrm{I}_{\mathrm{R} 5}=5 \\ 20 & \mathrm{I}_{\mathrm{R} 4}=5\end{array}$

$\begin{array}{ll}6 & 30 \\ 5 & 25 \\ 4 & 20 \\ 3 & 15 \\ 2 & 10 \\ 1 & 5\end{array}$

30

SD-TCT 


\begin{tabular}{|c|c|c|c|c|c|c|c|}
\hline $\mathrm{I}_{\mathrm{R} 3}=5$ & 3 & 15 & $\mathrm{I}_{\mathrm{R} 3}=5$ & 3 & 15 & & SD-TCT \\
\hline $\mathrm{I}_{\mathrm{R} 2}=5$ & 2 & 10 & $\mathrm{I}_{\mathrm{R} 2}=5$ & 2 & 10 & & \\
\hline $\mathrm{I}_{\mathrm{R} 1}=5$ & 1 & 5 & $\mathrm{I}_{\mathrm{R} 1}=5$ & 1 & 5 & & \\
\hline \multicolumn{8}{|l|}{$\underline{\text { Case-10 }}$} \\
\hline $\mathrm{I}_{\mathrm{R} 6}=3$ & 6 & 18 & $\mathrm{I}_{\mathrm{R} 1}=5$ & 6 & 30 & \multirow{6}{*}{30} & \multirow{6}{*}{ SD-TCT } \\
\hline $\mathrm{I}_{\mathrm{R} 5}=5.5$ & 5 & 27.5 & $\mathrm{I}_{\mathrm{R} 2}=5$ & 5 & 25 & & \\
\hline $\mathrm{I}_{\mathrm{R} 4}=5.5$ & 4 & 22 & $\mathrm{I}_{\mathrm{R} 3}=5$ & 4 & 20 & & \\
\hline $\mathrm{I}_{\mathrm{R} 3}=5.5$ & 3 & 16.5 & $\mathrm{I}_{\mathrm{R} 4}=5$ & 3 & 15 & & \\
\hline $\mathrm{I}_{\mathrm{R} 2}=5.5$ & 2 & 11 & $\mathrm{I}_{\mathrm{R} 5}=5$ & 2 & 10 & & \\
\hline $\mathrm{I}_{\mathrm{R} 1}=5.5$ & 1 & 5.5 & $\mathrm{I}_{\mathrm{R} 6}=5.5$ & 1 & 5.5 & & \\
\hline \multicolumn{8}{|l|}{ Case-11 } \\
\hline $\mathrm{I}_{\mathrm{R} 6}=3$ & 6 & 18 & $\mathrm{I}_{\mathrm{R} S}=4$ & 6 & 24 & \multirow{6}{*}{24} & \multirow{6}{*}{ SD-TCT } \\
\hline $\mathrm{I}_{R 5}=3.5$ & 5 & 17.5 & $\mathrm{I}_{\mathrm{R} 4}=4$ & 5 & 20 & & \\
\hline $\mathrm{I}_{\mathrm{R} 4}=4$ & 4 & 16 & $\mathrm{I}_{\mathrm{R} 1}=4$ & 4 & 16 & & \\
\hline $\mathrm{I}_{\mathrm{R} 3}=4.5$ & 3 & 13.5 & $\mathrm{I}_{\mathrm{R} 6}=4.5$ & 3 & 13.5 & & \\
\hline $\mathrm{I}_{\mathrm{R} 2}=5$ & 2 & 10 & $\mathrm{I}_{\mathrm{R} 3}=4.5$ & 2 & 9 & & \\
\hline $\mathrm{I}_{\mathrm{R} 1}=5.5$ & 1 & 5.5 & $\mathrm{I}_{\mathrm{R} 2}=5$ & 1 & 5 & & \\
\hline \multicolumn{8}{|l|}{$\underline{\text { Case-12 }}$} \\
\hline $\mathrm{I}_{\mathrm{R} 2}=4$ & 6 & 24 & $\mathrm{I}_{\mathrm{R} 6}=4$ & 6 & 24 & \multirow{6}{*}{24} & \multirow{6}{*}{$\begin{array}{l}\text { TCT/ } \\
\text { SD-TCT }\end{array}$} \\
\hline $\mathrm{I}_{\mathrm{R} 3}=4$ & 5 & 20 & $\mathrm{I}_{\mathrm{R} 5}=4.5$ & 5 & 22.5 & & \\
\hline $\mathrm{I}_{\mathrm{R} 4}=4$ & 4 & 16 & $\mathrm{I}_{\mathrm{R} 1}=4.5$ & 4 & 18 & & \\
\hline $\mathrm{I}_{\mathrm{R} 5}=4$ & 3 & 12 & $\mathrm{I}_{\mathrm{R} 4}=5$ & 3 & 15 & & \\
\hline $\mathrm{I}_{\mathrm{R} 6}=6$ & 2 & 12 & $\mathrm{I}_{\mathrm{R} 3}=5$ & 2 & 10 & & \\
\hline $\mathrm{I}_{\mathrm{R} 1}=6$ & 1 & 6 & $\mathrm{I}_{\mathrm{R} 2}=5$ & 1 & 2 & & \\
\hline \multicolumn{8}{|l|}{$\underline{\text { Case-13 }}$} \\
\hline $\mathrm{I}_{\mathrm{R} 1}=3$ & 6 & 18 & $\mathrm{I}_{\mathrm{R} 4}=4$ & 6 & 24 & \multirow{6}{*}{24} & \multirow{6}{*}{ SD-TCT } \\
\hline $\mathrm{I}_{\mathrm{R} 6}=3$ & 5 & 15 & $\mathrm{I}_{\mathrm{R} 3}=4$ & 5 & 20 & & \\
\hline $\mathrm{I}_{\mathrm{R} 5}=5$ & 4 & 20 & $\mathrm{I}_{\mathrm{R} 2}=4$ & 4 & 16 & & \\
\hline $\mathrm{I}_{\mathrm{R} 4}=5$ & 3 & 15 & $\mathrm{I}_{\mathrm{R} 1}=4.5$ & 3 & 13.5 & & \\
\hline $\mathrm{I}_{\mathrm{R} 3}=5$ & 2 & 10 & $\mathrm{I}_{\mathrm{R} 5}=4.5$ & 2 & 9 & & \\
\hline $\mathrm{I}_{\mathrm{R} 2}=5$ & 1 & 5 & $\mathrm{I}_{\mathrm{R} 6}=5$ & 1 & 5 & & \\
\hline \multicolumn{8}{|l|}{$\underline{\text { Case-14 }}$} \\
\hline $\mathrm{I}_{\mathrm{R} 6}=3$ & 6 & 18 & $\mathrm{I}_{\mathrm{R} 5}=4.5$ & 6 & 27 & \multirow{6}{*}{27} & \multirow{6}{*}{ SD-TCT } \\
\hline $\mathrm{I}_{\mathrm{R} 5}=4$ & 5 & 20 & $\mathrm{I}_{\mathrm{R} 1}=4.5$ & 5 & 22.5 & & \\
\hline $\mathrm{I}_{\mathrm{R} 4}=5$ & 4 & 20 & $\mathrm{I}_{\mathrm{R} 2}=5$ & 4 & 20 & & \\
\hline $\mathrm{I}_{\mathrm{R} 3}=5.5$ & 3 & 16.5 & $\mathrm{I}_{\mathrm{R} 4}=5$ & 3 & 15 & & \\
\hline $\mathrm{I}_{\mathrm{R} 2}=6$ & 2 & 12 & $\mathrm{I}_{\mathrm{R} 6}=5$ & 2 & 10 & & \\
\hline $\mathrm{I}_{\mathrm{R} 1}=6$ & 1 & 6 & $\mathrm{I}_{\mathrm{R} 3}=5.5$ & 1 & 5.5 & & \\
\hline \multicolumn{8}{|l|}{$\underline{\text { Case-15 }}$} \\
\hline $\mathrm{I}_{\mathrm{R} 6}=5.5$ & 6 & 33 & $\mathrm{I}_{\mathrm{R} 1}=5$ & 6 & 30 & \multirow{6}{*}{33} & \multirow{6}{*}{ TCT } \\
\hline $\mathrm{I}_{\mathrm{R} 5}=5.5$ & 5 & 27.5 & $\mathrm{I}_{\mathrm{R} 5}=5$ & 5 & 25 & & \\
\hline $\mathrm{I}_{\mathrm{R} 4}=5.5$ & 4 & 22 & $\mathrm{I}_{\mathrm{R} 4}=5.5$ & 4 & 22 & & \\
\hline $\mathrm{I}_{\mathrm{R} 3}=5.5$ & 3 & 16.5 & $\mathrm{I}_{\mathrm{R} 2}=5.5$ & 3 & 16.5 & & \\
\hline $\mathrm{I}_{\mathrm{R} 2}=5.5$ & 2 & 11 & $\mathrm{I}_{\mathrm{R} 3}=6$ & 2 & 12 & & \\
\hline $\mathrm{I}_{\mathrm{R} 1}=5.5$ & 1 & 5.5 & $\mathrm{I}_{\mathrm{R} 6}=6$ & 1 & 6 & & \\
\hline \multicolumn{8}{|l|}{$\underline{\text { Case-16 }}$} \\
\hline $\mathrm{I}_{\mathrm{R} 1}=4$ & 6 & 24 & $\mathrm{I}_{\mathrm{R} 6}=4.5$ & 6 & 27 & & \\
\hline $\mathrm{I}_{\mathrm{R} 2}=5$ & 5 & 25 & $\mathrm{I}_{\mathrm{R} 1}=4.5$ & 5 & 22.5 & & \\
\hline $\mathrm{I}_{\mathrm{R} 6}=5$ & 4 & 20 & $\mathrm{I}_{\mathrm{R} 3}=5$ & 4 & 20 & & \\
\hline $\mathrm{I}_{\mathrm{RS}}=5.5$ & 3 & 16.5 & $\mathrm{I}_{\mathrm{R} 5}=5.5$ & 3 & 16.5 & 27 & SD-TCT \\
\hline $\mathrm{I}_{\mathrm{R} 4}=5.5$ & 2 & 11 & $\mathrm{I}_{\mathrm{R} 4}=5.5$ & 2 & 11 & & \\
\hline $\mathrm{I}_{\mathrm{R} 3}=5.5$ & 1 & 5.5 & $\mathrm{I}_{\mathrm{R} 2}=5.5$ & 1 & 5.5 & & \\
\hline
\end{tabular}




\begin{tabular}{|c|c|c|c|c|c|c|c|}
\hline $\mathrm{I}_{\mathrm{R} 6}=3$ & 6 & 18 & $\mathrm{I}_{\mathrm{R} 6}=3$ & 6 & 18 & & \\
\hline $\mathrm{I}_{\mathrm{R} 5}=3$ & 5 & 15 & $\mathrm{I}_{\mathrm{R} 5}=3$ & 5 & 15 & & \\
\hline $\mathrm{I}_{\mathrm{R} 4}=3$ & 4 & 12 & $\mathrm{I}_{\mathrm{R} 4}=3$ & 4 & 12 & 18 & TCT/ \\
\hline $\mathrm{I}_{\mathrm{R} 3}=3$ & 3 & 9 & $\mathrm{I}_{\mathrm{R} 3}=3$ & 3 & 9 & & SD-TCT \\
\hline $\mathrm{I}_{\mathrm{R} 2}=3$ & 2 & 6 & $\mathrm{I}_{\mathrm{R} 2}=3$ & 2 & 6 & & \\
\hline $\mathrm{I}_{\mathrm{R} 1}=3$ & 1 & 3 & $I_{R 1}=3$ & 1 & 3 & & \\
\hline
\end{tabular}

\section{Shading Cases for a 5x6 Array}

The shading cases considered for analyzing the shade dispersion in a $5 \times 6 \mathrm{SD}-$ TCT array configuration are illustrated in Figure 9. Figure 9 (a) represents the shading pattern in TCT array connection and 9(b) represents the shade dispersion in SD-TCT arrangement with number logic approach. In non-shading case, i.e., case- $\mathrm{U}, 30$ modules in a $6 \times 5 \mathrm{PV}$ array receive full irradiance at STC of $1000 \mathrm{~W} / \mathrm{m}^{2}$.
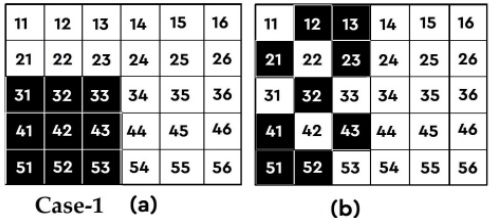

(b)

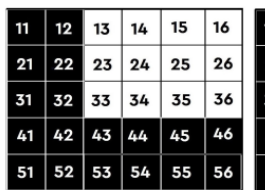

Case-4 (a)

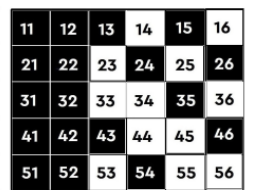

(b)

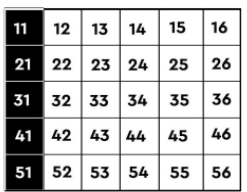

Case- 7 (a)

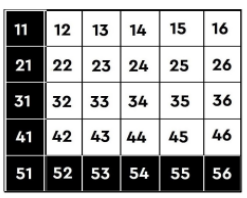

Case-10 (a)

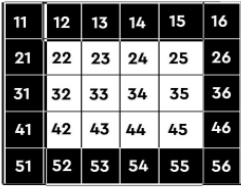

Case-13 (a)

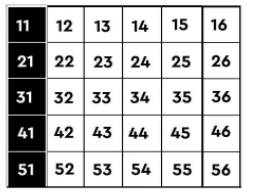

(b)

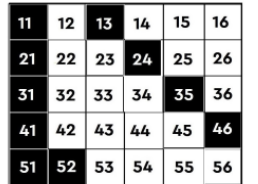

(b)

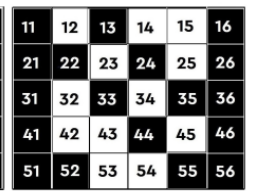

(b)

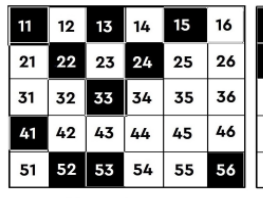

Case-16 (a)

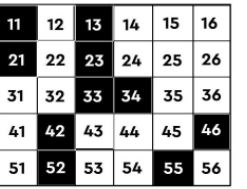

(b)

Figure 9. Shade disper



Case-2 (a)

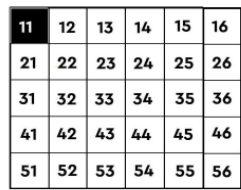

Case-5 (a)



Case-8 (a)

(b)

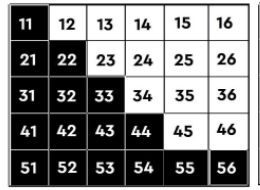

Case-11 (a)

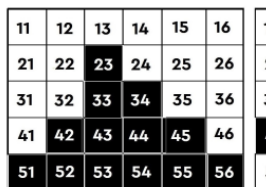

Case-14 (a)



(b)

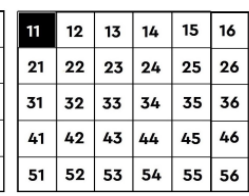

(b)

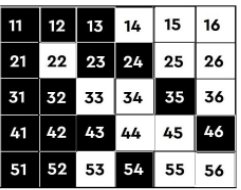

(b)



Case-17 (a)

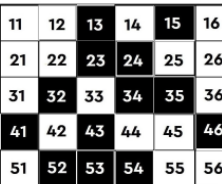

(b)

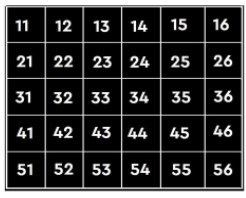

(b)

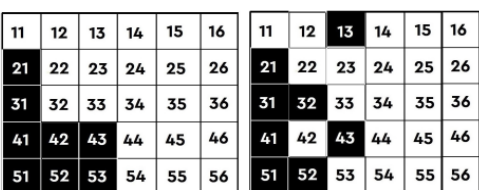

(b)



Case-6 (a)

(b)



\begin{tabular}{|l|l|l|l|l|l|l|l|l|l|l|l|}
\hline 11 & 12 & 13 & 14 & 15 & 16 \\
\hline 21 & 22 & 23 & 24 & 25 & 26 \\
\hline 31 & 32 & 33 & 34 & 35 & 36 & 12 & 13 & 14 & 15 & 16 \\
\hline 41 & 42 & 43 & 44 & 45 & 46 & 23 & 24 & 25 & 26 \\
\hline 51 & 52 & 53 & 54 & 55 & 56 & 33 & 34 & 35 & 36 \\
\hline 51 & 42 & 43 & 44 & 45 & 46 \\
\hline 51 & 52 & 53 & 54 & 55 & 56 \\
\hline
\end{tabular}

Case-12 (a)

(b)



(b)

\begin{tabular}{|l|l|l|l|l|l|}
\hline 11 & 12 & 13 & 14 & 15 & 16 \\
\hline 21 & 22 & 23 & 24 & 25 & 26 \\
\hline 31 & 32 & 33 & 34 & 35 & 36 \\
\hline 41 & 42 & 43 & 44 & 45 & 46 \\
\hline 51 & 52 & 53 & 54 & 55 & 56 \\
\hline \multicolumn{7}{|c|}{} \\
\hline
\end{tabular}

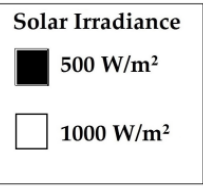

Solar Irradiance

$1000 \mathrm{~W} / \mathrm{m}^{2}$

(a) TCT (b) SD-TCT configuration

\section{Shading Cases for a $6 \times 5$ Array}

Shading cases for shadow dispersion analysis in a $6 \times 5$ SD-TCT configuration are shown in Figure 10. Figure 10(a) represents the shading pattern in TCT array connection, 
and 10(b) represents the shade dispersion in SD-TCT arrangement with a number logic approach as explained in the formation of the SD-TCT section. In un-shading case, i.e., case- $\mathrm{U}, 30$ modules in a $6 \times 5 \mathrm{PV}$ array receive full irradiance at STC is $1000 \mathrm{~W} / \mathrm{m}^{2}$.

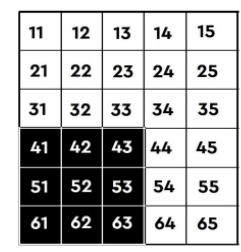

Case-1 (a)



Case-4 (a)

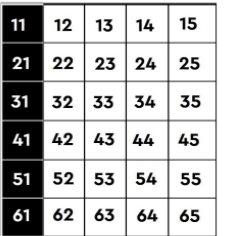

Case- 7 (a)


Case-10 (a)

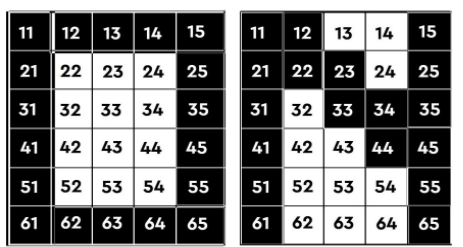
Case-13 (a)

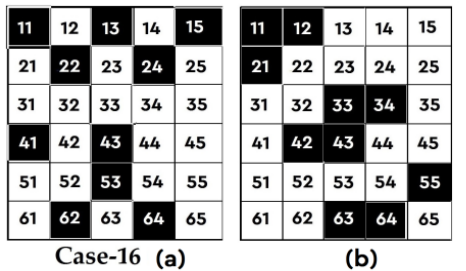

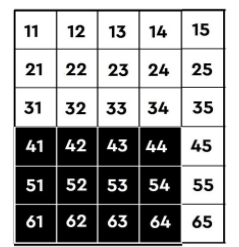

Case-2 (a)

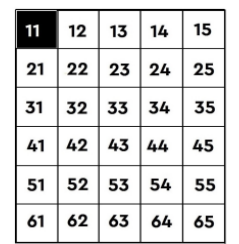

Case-5 (a)



Case-8 (a)

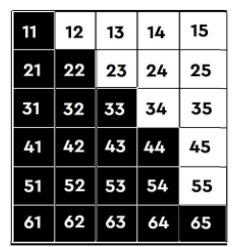

Case-11 (a)

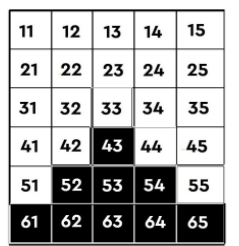

Case-14 (a)

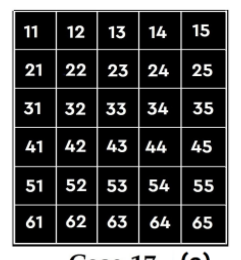

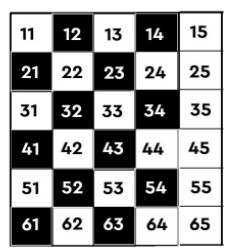

(b)



(b)

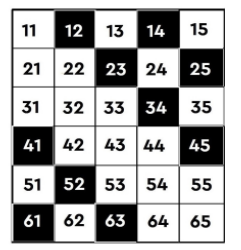

(b)

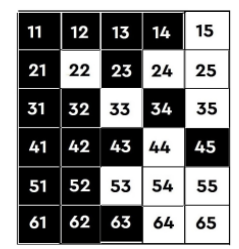

(b)

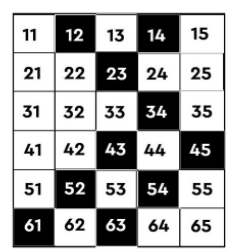

(b)

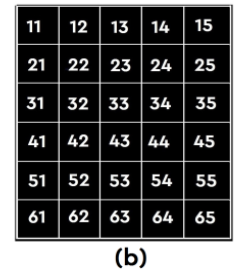

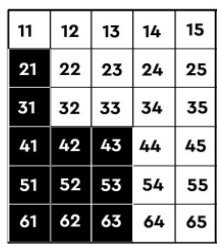

Case-3 (a)

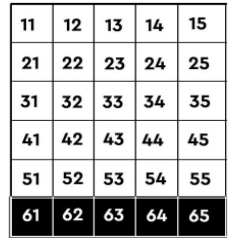

Case-6 (a)

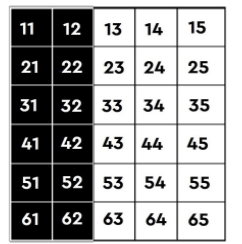

Case-9 (a)



Case-12 (a)

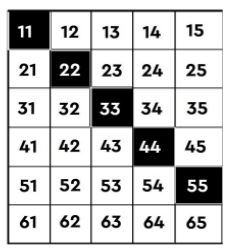

Case-15 (a)

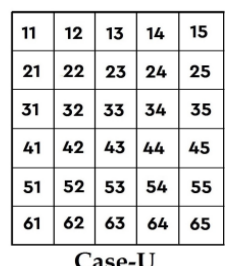

Case-U

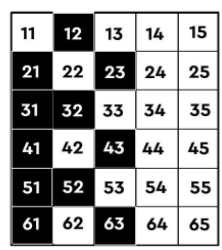

(b)

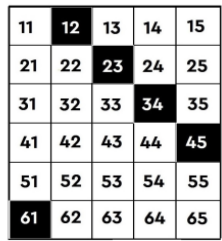

(b)

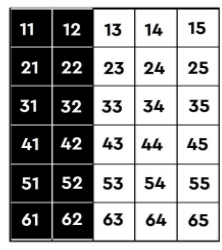

(b)

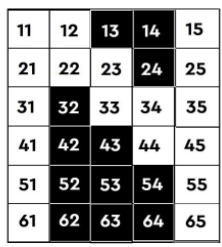

(b)

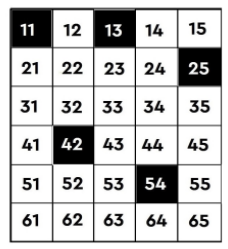

(b)

Solar Irradiance

$500 \mathrm{~W} / \mathrm{m}^{2}$

$1000 \mathrm{~W} / \mathrm{m}^{2}$

Figure 10. Shade dispersion analysis in a 6x5array under various shadings: (a) TCT (b) SD-TCT configuration

Suppose considering case- 6 , PV modules in the sixth row of a $6 \times 5$ TCT array are partially shaded with an irradiance of $500 \mathrm{~W} / \mathrm{m}^{2}$ and other five rows are fully illuminated on sun irradiance as elaborated in Figure-10:case-6(a). The shaded modules in the $6^{\text {th }}$ row are physically moved within a column based on the shade dispersion number logic approach, but electrical wiring is unchanged, as shown in Figure-10:case-6(b). The $6^{\text {th }}-$ row modules in 61 to 66 are shaded in the TCT array and the proposed SD-TCT 
arrangement provides shaded modules $61,12,23,34,45$, which are positioned in different rows in a $6 \times 5 \mathrm{PV}$ array and thus shades are spread in an SD-TCT arrangement throughout the PV array. In the same way, shadows are spread in the entire PV array system for other cases.

\section{Results and Discussion}

\section{Performance Analysis}

To evaluate the performance of $6 \times 6,6 \times 5$ and $5 \times 6$ array size SP, TCT and proposed SD-TCT arrangements, three factors including Global Maximum Power Point (GMPP), mismatch losses (ML), \% power improvement in SD-TCT under different shading cases are considered in this paper, which are displayed in Figures 7, 9 and 10, respectively. The ML exists between the parameters of the PV module under SC, as the modules obtain different intensities of solar radiation. ML is the distinction between the received peak power in the un-shaded case with an irradiance of $1000 \mathrm{~W} / \mathrm{m}^{2}\left(\mathrm{GMPP}_{\mathrm{uni}}\right)$ and the maximum power under various shadings $\left(\mathrm{GMPP}_{\mathrm{SCs}}\right)$.

$$
\begin{aligned}
& \text { Mismatch losses }(M L)=G M P P_{u n i}-G M P P_{S C s} \quad---(8) \\
& \text { Power improvement in } S D-T C T(\%)=\frac{G M P P_{S D . T C T}-G M P P_{T C T}}{G M P P_{S D . T C T}} \quad---(9) \\
& \text { Where, GMPP = Global maximum power point in watts }(\mathrm{W}) \\
& M L \quad=\text { Mismatch Losses in watts(W) } \\
& G M P P_{\text {uni }} \quad=\text { GMPP at Uniform irradiance of } 1000 \mathrm{~W} / \mathrm{m}^{2} \text { in watts(W) } \\
& G M P P_{S C s}=\text { GMPP at different shading conditions in watts(W) } \\
& G M P P_{S D . T C T}=\text { GMPP of SD-TCT type of array configuration in watts }(\mathrm{W}) \\
& G M P P_{T C T} \quad=\text { GMPP of TCT type of array configuration in watts(W) } \\
& S D-T C T=\text { Shaded Dispersion Based TCT configuration. }
\end{aligned}
$$

\begin{tabular}{|c|c|c|c|c|c|c|c|c|}
\hline \multirow[b]{3}{*}{ Cases } & \multicolumn{6}{|c|}{$6 \times 6$ array configurations } & \multirow{3}{*}{$\begin{array}{c}\text { Minimum } \\
\text { ML } \\
(\mathbf{W})\end{array}$} & \multirow{3}{*}{$\begin{array}{c}\text { Best } \\
\text { Configuration }\end{array}$} \\
\hline & \multicolumn{2}{|c|}{$\mathbf{S - P}$} & \multicolumn{2}{|c|}{ T-C-T } & \multicolumn{2}{|c|}{ SD- TCT } & & \\
\hline & $\begin{array}{c}\text { GMPP } \\
\text { (W) }\end{array}$ & $\begin{array}{l}\text { ML } \\
\text { (W) }\end{array}$ & $\begin{array}{c}\text { GMPP } \\
\text { (W) }\end{array}$ & $\begin{array}{l}\text { ML } \\
\text { (W) }\end{array}$ & $\begin{array}{c}\text { GMPP } \\
\text { (W) }\end{array}$ & $\begin{array}{l}\mathrm{ML} \\
(\mathrm{W})\end{array}$ & & \\
\hline $\mathbf{U}$ & 9620 & 0 & 9620 & 0 & 9620 & 0 & 0 & ALL \\
\hline 1 & 7384 & 2236 & 7714 & 1906 & 8309 & 1311 & 1311 & Proposed \\
\hline 2 & 5979 & 3641 & 6155 & 3465 & 7513 & 2107 & 2107 & Proposed \\
\hline 3 & 7359 & 2261 & 7661 & 1959 & 8128 & 1492 & 1492 & Proposed \\
\hline 4 & 5208 & 4412 & 5433 & 4187 & 6815 & 2805 & 2805 & Proposed \\
\hline 5 & 8869 & 751 & 9352 & 268 & 9352 & 268 & 268 & TCT, Proposed \\
\hline 6 & 7974 & 1646 & 7974 & 1646 & 8834 & 786 & 786 & Proposed \\
\hline 7 & 8834 & 786 & 8834 & 786 & 8834 & 786 & 786 & ALL \\
\hline 8 & 6328 & 3292 & 6328 & 3292 & 8049 & 1571 & 1571 & Proposed \\
\hline 9 & 8049 & 1571 & 8049 & 1571 & 8049 & 1571 & 1571 & ALL \\
\hline 10 & 7350 & 2270 & 7323 & 2297 & 8128 & 1492 & 1492 & Proposed \\
\hline 11 & 5190 & 4430 & 5510 & 4110 & 6853 & 2767 & 2767 & Proposed \\
\hline 12 & 6617 & 3003 & 6778 & 2842 & 7057 & 2563 & 2563 & Proposed \\
\hline 13 & 5346 & 4274 & 5433 & 4187 & 6752 & 2868 & 2868 & Proposed \\
\hline 14 & 5422 & 4198 & 6000 & 3620 & 7660 & 1960 & 1960 & Proposed \\
\hline
\end{tabular}

Table 5. GMPP and ML of a $6 \times 6$ array size configurations 


\begin{tabular}{|lllllllll|}
$\mathbf{1 5}$ & 7974 & 1646 & 8834 & 786 & 8511 & 1109 & 786 & TCT \\
$\mathbf{1 6}$ & 6018 & 3602 & 7214 & 2406 & 7745 & 1875 & 1875 & Proposed \\
$\mathbf{1 7}$ & 4917 & 4703 & 4917 & 4703 & 4917 & 4703 & 4703 & ALL \\
\hline
\end{tabular}

Table 6. GMPP and ML of a $6 \times 5$ array size configurations

\begin{tabular}{|c|c|c|c|c|c|c|c|c|}
\hline \multirow[b]{3}{*}{ Cases } & \multicolumn{6}{|c|}{$6 \times 5$ array configurations } & \multirow{3}{*}{$\begin{array}{c}\text { Minimum } \\
\text { ML } \\
(\mathbf{W})\end{array}$} & \multirow{3}{*}{$\begin{array}{c}\text { Best } \\
\text { Configuration }\end{array}$} \\
\hline & \multicolumn{2}{|c|}{$\mathbf{S - P}$} & \multicolumn{2}{|c|}{ T-C-T } & \multicolumn{2}{|c|}{ SD-TCT } & & \\
\hline & $\begin{array}{c}\text { GMPP } \\
\text { (W) }\end{array}$ & $\begin{array}{l}\text { ML } \\
(\mathrm{W})\end{array}$ & $\begin{array}{l}\text { GMPP } \\
(W)\end{array}$ & $\begin{array}{l}\text { ML } \\
(\mathrm{W})\end{array}$ & $\begin{array}{c}\text { GMPP } \\
\text { (W) }\end{array}$ & $\begin{array}{l}\mathrm{ML} \\
(\mathrm{W})\end{array}$ & & \\
\hline $\mathbf{U}$ & 8017 & 0 & 8017 & 0 & 8017 & 0 & 0 & ALL \\
\hline 1 & 5792 & 2225 & 6048 & 1969 & 6685 & 1332 & 1332 & Proposed \\
\hline 2 & 5094 & 2923 & 5263 & 2754 & 6445 & 1572 & 1572 & Proposed \\
\hline 3 & 5763 & 2254 & 6005 & 2012 & 6518 & 1499 & 1499 & Proposed \\
\hline 4 & 4301 & 3716 & 4511 & 3506 & 5307 & 2710 & 2710 & Proposed \\
\hline 5 & 7307 & 710 & 7716 & 301 & 7716 & 301 & 301 & TCT, Proposed \\
\hline 6 & 6645 & 1372 & 6645 & 1372 & 7307 & 710 & 710 & Proposed \\
\hline 7 & 7231 & 786 & 7231 & 786 & 7231 & 786 & 786 & ALL \\
\hline 8 & 5273 & 2744 & 5273 & 2744 & 6597 & 1420 & 1420 & Proposed \\
\hline 9 & 6445 & 1572 & 6445 & 1572 & 6445 & 1572 & 1572 & ALL \\
\hline 10 & 6022 & 1995 & 5994 & 2023 & 6597 & 1420 & 1420 & Proposed \\
\hline 11 & 4291 & 3726 & 4566 & 3451 & 5200 & 2817 & 2817 & Proposed \\
\hline 12 & 5760 & 2257 & 5907 & 2110 & 6049 & 1968 & 1968 & Proposed \\
\hline 13 & 4302 & 3715 & 4511 & 3506 & 5228 & 2789 & 2789 & Proposed \\
\hline 14 & 4898 & 3119 & 5244 & 2773 & 6686 & 1331 & 1331 & Proposed \\
\hline 15 & 6645 & 1372 & 7307 & 710 & 6990 & 1027 & 710 & TCT \\
\hline 16 & 4864 & 3153 & 6190 & 1827 & 6597 & 1420 & 1420 & Proposed \\
\hline 17 & 4097 & 3920 & 4097 & 3920 & 4097 & 3920 & 3920 & ALL \\
\hline
\end{tabular}

Table 7. GMPP and ML of a $5 \times 6$ array size configurations

\begin{tabular}{|c|c|c|c|c|c|c|c|c|}
\hline \multirow[b]{3}{*}{ Cases } & \multicolumn{6}{|c|}{$5 \times 6$ array configurations } & \multirow{3}{*}{$\begin{array}{c}\text { Minimum } \\
\text { ML } \\
(\mathbf{W})\end{array}$} & \multirow{3}{*}{$\begin{array}{c}\text { Best } \\
\text { Configuration }\end{array}$} \\
\hline & \multicolumn{2}{|c|}{$\mathbf{S}-\mathbf{P}$} & \multicolumn{2}{|c|}{ T-C-T } & \multicolumn{2}{|c|}{ SD-TCT } & & \\
\hline & $\begin{array}{c}\text { GMPP } \\
\text { (W) }\end{array}$ & $\begin{array}{l}\text { ML } \\
(\mathrm{W})\end{array}$ & $\begin{array}{c}\text { GMPP } \\
\text { (W) }\end{array}$ & $\begin{array}{l}\mathrm{ML} \\
(\mathrm{W})\end{array}$ & $\begin{array}{c}\text { GMPP } \\
(\mathrm{W})\end{array}$ & $\begin{array}{l}\text { ML } \\
(\mathrm{W})\end{array}$ & & \\
\hline $\mathbf{U}$ & 8011 & 0 & 8011 & 0 & 8011 & 0 & 0 & ALL \\
\hline 1 & 6137 & 1874 & 6340 & 1671 & 6783 & 1228 & 1228 & Proposed \\
\hline 2 & 5529 & 2482 & 5699 & 2312 & 6307 & 1704 & 1704 & Proposed \\
\hline 3 & 6135 & 1876 & 6459 & 1552 & 6871 & 1140 & 1140 & Proposed \\
\hline 4 & 4322 & 3689 & 4473 & 3538 & 5549 & 2462 & 2462 & Proposed \\
\hline 5 & 7386 & 625 & 7763 & 248 & 7763 & 248 & 248 & TCT, Proposed \\
\hline 6 & 6365 & 1646 & 6365 & 1646 & 7096 & 915 & 915 & Proposed \\
\hline 7 & 7357 & 654 & 7357 & 654 & 7357 & 654 & 654 & ALL \\
\hline 8 & 4531 & 3480 & 4719 & 3292 & 6307 & 1704 & 1704 & Proposed \\
\hline 9 & 6703 & 1308 & 6703 & 1308 & 6703 & 1308 & 1308 & ALL \\
\hline 10 & 5868 & 2143 & 5845 & 2166 & 6703 & 1308 & 1308 & Proposed \\
\hline 11 & 4348 & 3663 & 4651 & 3360 & 5754 & 2257 & 2257 & Proposed \\
\hline 12 & 5529 & 2482 & 5699 & 2312 & 6307 & 1704 & 1704 & Proposed \\
\hline 13 & 4322 & 3689 & 4473 & 3538 & 5549 & 2462 & 2462 & Proposed \\
\hline 14 & 4450 & 3561 & 4733 & 3278 & 6210 & 1801 & 1801 & Proposed \\
\hline 15 & 6434 & 1577 & 7357 & 654 & 7357 & 654 & 654 & TCT, Proposed \\
\hline 16 & 5377 & 2634 & 6515 & 1496 & 6703 & 1308 & 1308 & Proposed \\
\hline
\end{tabular}


17

ALL

Table 8. Power improvement in SD-TCT compared to SP and TCT array configurations

\begin{tabular}{|c|c|c|c|c|c|c|c|c|c|}
\hline \multirow{3}{*}{ Cases } & \multicolumn{3}{|c|}{$6 \times 6$ SPV array } & \multicolumn{3}{|c|}{$6 \times 5$ SPV array } & \multicolumn{3}{|c|}{$5 \times 6$ SPV array } \\
\hline & \multirow{2}{*}{$\begin{array}{c}\text { SD-TCT } \\
\text { Configu } \\
\text { ration: } \\
\text { GMPP } \\
\text { (W) }\end{array}$} & \multicolumn{2}{|c|}{$\begin{array}{l}\% \text { Power } \\
\text { improvement in } \\
\text { SD-TCT } \\
\text { compared to }\end{array}$} & \multirow{2}{*}{$\begin{array}{l}\text { SD-TCT } \\
\text { Configur } \\
\text { ation: } \\
\text { GMPP } \\
\text { (W) }\end{array}$} & \multicolumn{2}{|c|}{$\begin{array}{c}\% \text { Power } \\
\text { improvement in } \\
\text { SD-TCT } \\
\text { compared to }\end{array}$} & \multirow{2}{*}{$\begin{array}{l}\text { SD-TCT } \\
\text { Configur } \\
\text { ation: } \\
\text { GMPP } \\
\text { (W) }\end{array}$} & \multicolumn{2}{|c|}{$\begin{array}{c}\text { \% Power } \\
\text { improvement in } \\
\text { SD-TCT } \\
\text { compared to }\end{array}$} \\
\hline & & S-P & T-C-T & & S-P & T-C-T & & S-P & T-C-T \\
\hline $\mathbf{U}$ & 9620 & 0 & 0 & 8017 & 0 & 0 & 8011 & 0 & 0 \\
\hline 1 & 8309 & 11.13 & 7.16 & 6685 & 13.35 & 9.52 & 6783 & 9.52 & 6.53 \\
\hline 2 & 7513 & 20.41 & 18.07 & 6445 & 20.96 & 18.33 & 6307 & 12.33 & 9.64 \\
\hline 3 & 8128 & 9.46 & 5.74 & 6518 & 11.58 & 7.87 & 6871 & 10.71 & 5.99 \\
\hline 4 & 6815 & 23.58 & 20.27 & 5307 & 18.95 & 14.99 & 5549 & 22.11 & 19.39 \\
\hline 5 & 9352 & 5.16 & 0 & 7716 & 5.81 & 0 & 7763 & 4.85 & 0 \\
\hline 6 & 8834 & 9.73 & 9.73 & 7307 & 9.05 & 9.05 & 7096 & 10.30 & 10.30 \\
\hline 7 & 8834 & 0 & 0 & 7231 & 0 & 0 & 7357 & 0 & 0 \\
\hline 8 & 8049 & 21.38 & 21.38 & 6597 & 20.06 & 20.06 & 6307 & 28.15 & 25.17 \\
\hline 9 & 8049 & 0 & 0 & 6445 & 0 & 0 & 6703 & 0 & 0 \\
\hline 10 & 8128 & 9.57 & 9.90 & 6597 & 8.71 & 9.14 & 6703 & 12.45 & 12.80 \\
\hline 11 & 6853 & 24.26 & 19.59 & 5200 & 17.48 & 12.19 & 5754 & 24.43 & 19.16 \\
\hline 12 & 7057 & 6.23 & 3.95 & 6049 & 4.77 & 2.34 & 6307 & 12.33 & 9.64 \\
\hline 13 & 6752 & 20.82 & 19.53 & 5228 & 17.71 & 13.71 & 5549 & 22.11 & 19.39 \\
\hline 14 & 7660 & 29.21 & 21.67 & 6686 & 26.74 & 21.56 & 6210 & 28.34 & 23.78 \\
\hline 15 & 8511 & 6.30 & -3.79 & 6990 & 4.93 & -4.53 & 7357 & 12.54 & 0 \\
\hline 16 & 7745 & 22.29 & 6.85 & 6597 & 26.26 & 6.16 & 6703 & 19.78 & 2.80 \\
\hline 17 & 4917 & 0 & 0 & 4097 & 0 & 0 & 4096 & 0 & 0 \\
\hline
\end{tabular}

The findings of the simulation can be inferred:

$>$ Under full irradiance on the PV array (case-U), the global maximum powers are $9620 \mathrm{~W}, 8017 \mathrm{~W}$, and $8011 \mathrm{~W}$ for $6 \times 6,6 \times 5$, and $5 \times 6$ array SP, TCT, and proposed SD-TCT configurations, respectively.

$>$ In shading cases-7, 9 and 17: All types of configurations have similar GMPP and minimum ML.

$>$ The TCT and SD-TCT arrangements of power outputs are the same as the shading case-5.

$>$ In $6 \times 6,6 \times 5$, and $5 \times 6$ size solar PV arrays, the proposed SD-TCT type of configuration has the highest GMPP's and minimum mismatch losses (ML) in most of the shading cases except in diagonal shape partial shading case- 15 .

Compared with the SP and TCT arrangement, the power of SD-TCT has been enhanced, except for the shading cases 5, 7, 9 and 17.

\section{Performance Characteristics of Array Configurations}

Figures 11,12 and 13 show P-V characteristics of $6 \times 6,6 \times 5$, and $5 \times 6$ array SDTCT arrangements under different shading cases. The results find that the performance of a proposed SD-TCT is superior to other types of arrangements. 


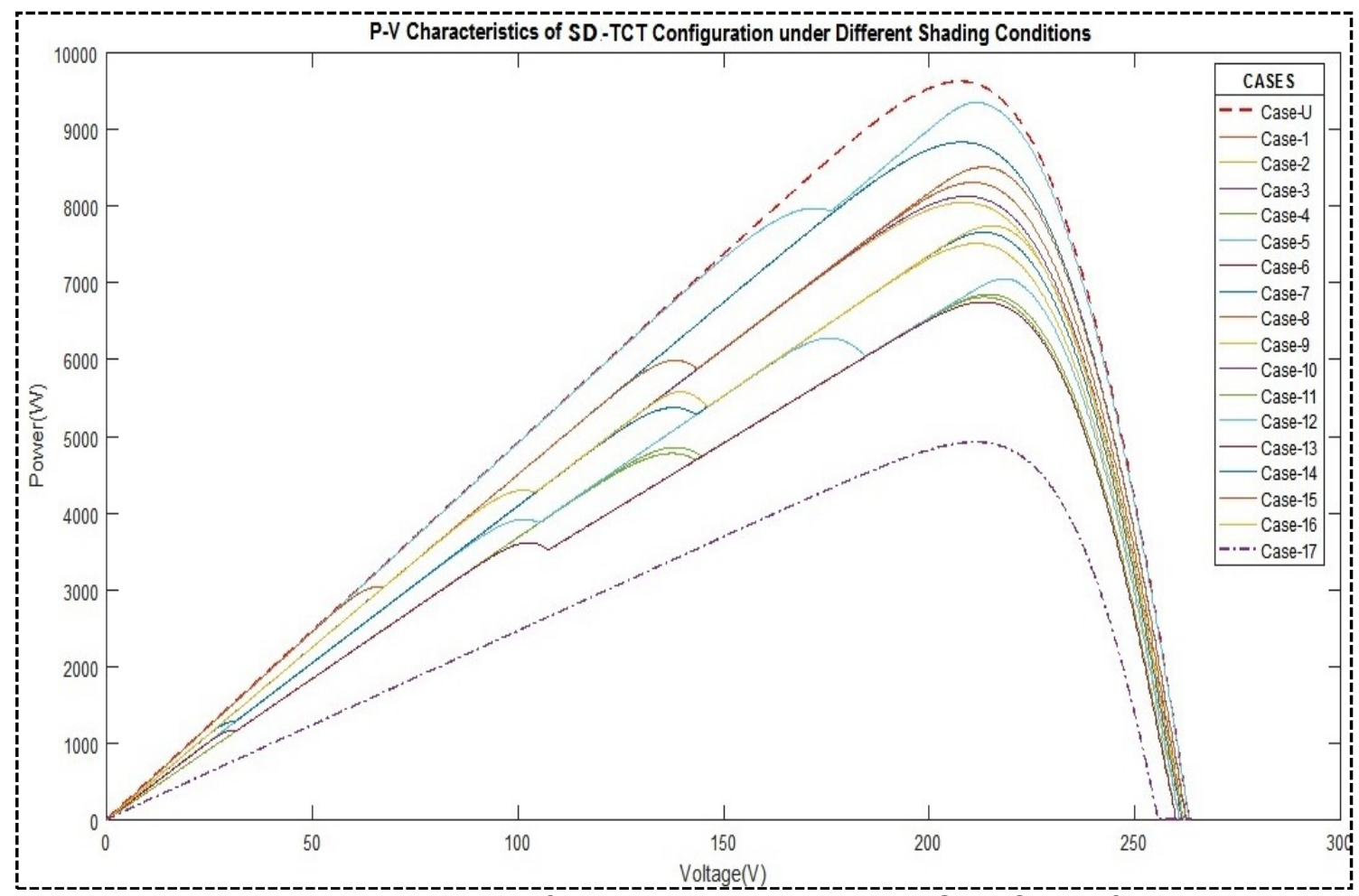

Figure 11. $\mathrm{P}-\mathrm{V}$ characteristics for $6 \times 6$ array size proposed SD-TCT configurations

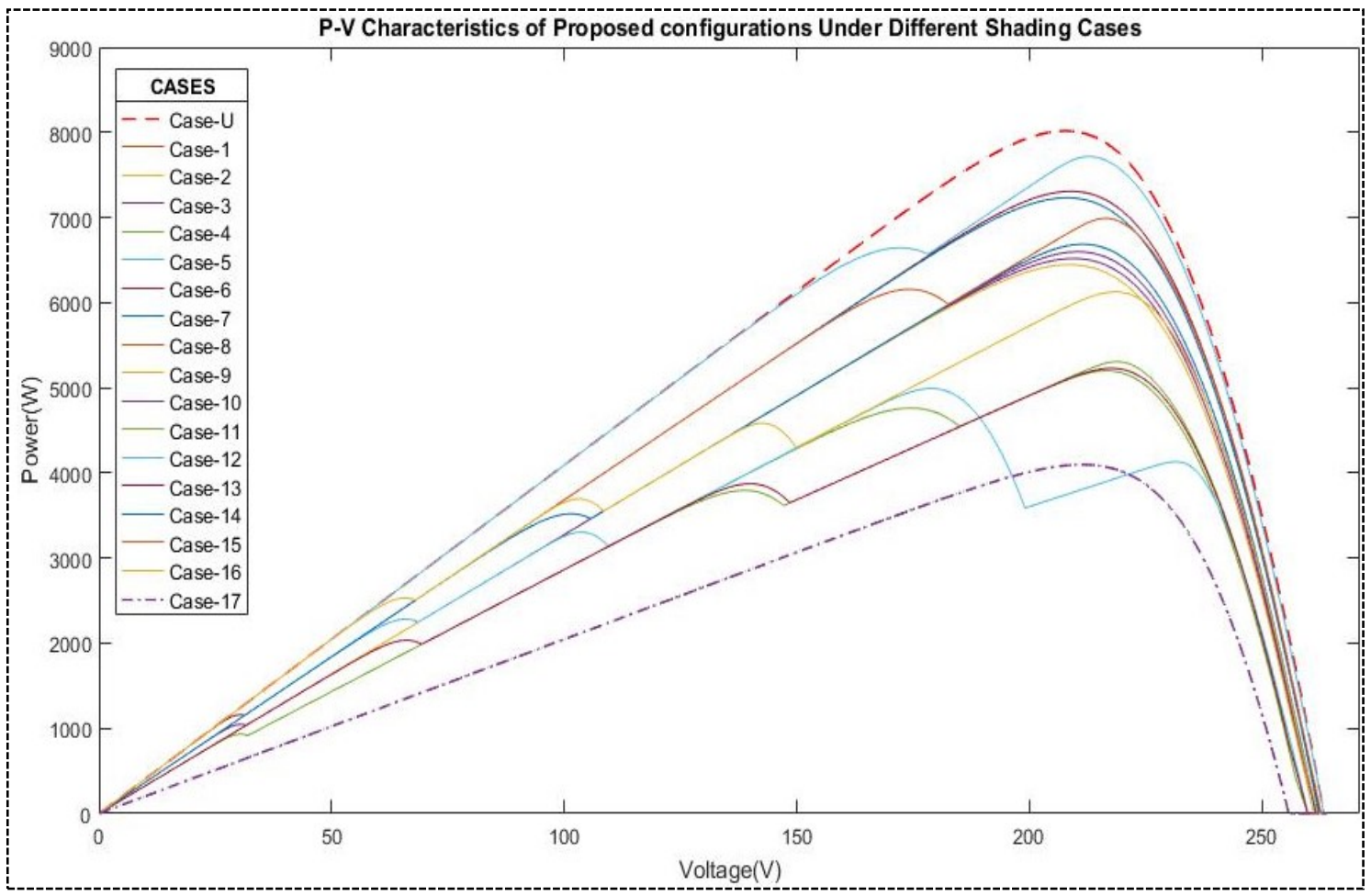

Figure 12. $\mathrm{P}-\mathrm{V}$ characteristics for $6 \times 5$ array size proposed SD-TCT configurations 




Figure 13. P-V characteristics for $5 \times 6$ array size proposed SD-TCT configurations



Figure 14. Comparison of GMPP's under different shading cases in $6 \times 6$ array size configurations 


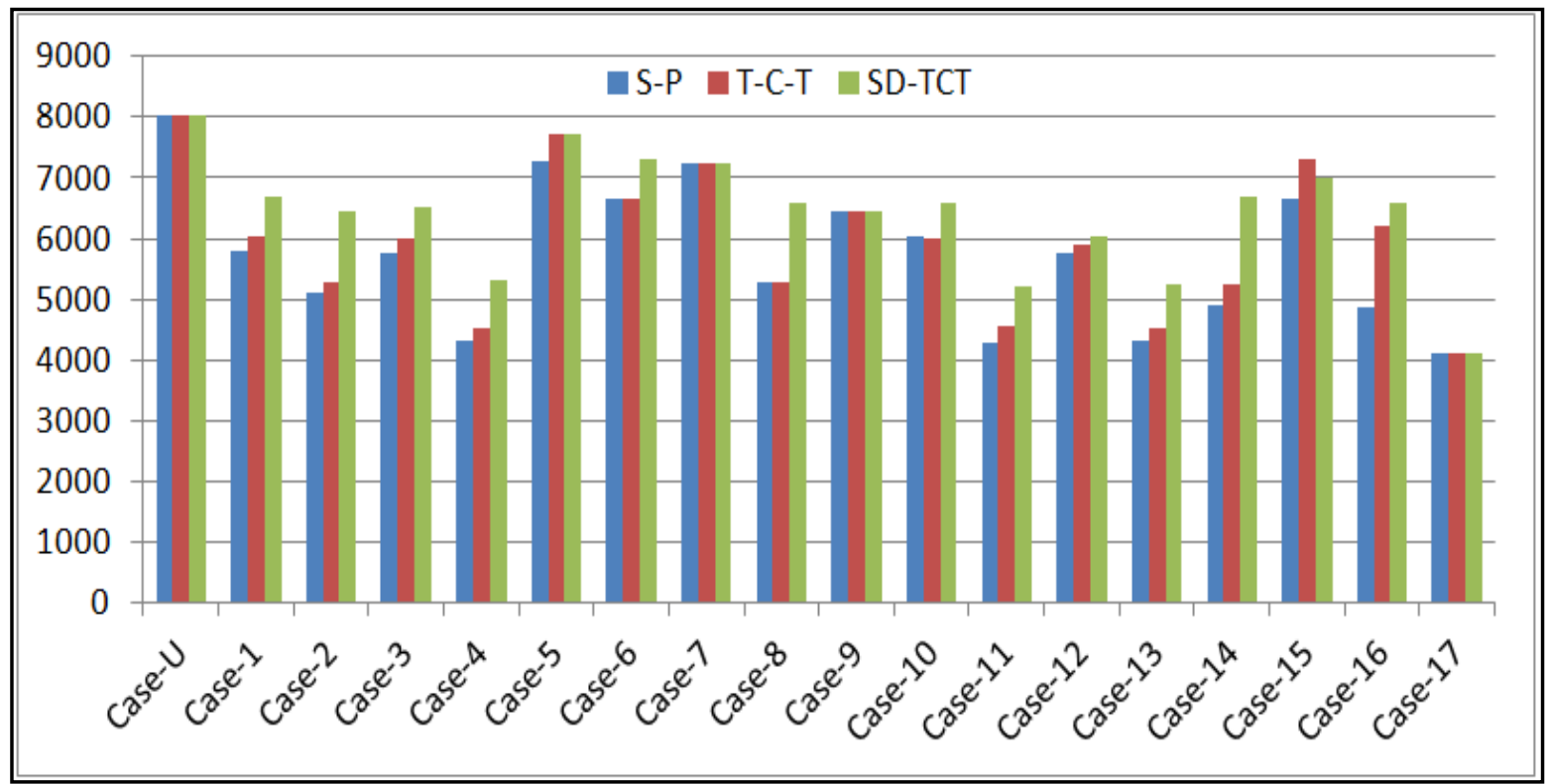

Figure 15. Comparison of GMPP's under different shading cases in $6 \times 5$ array size configurations

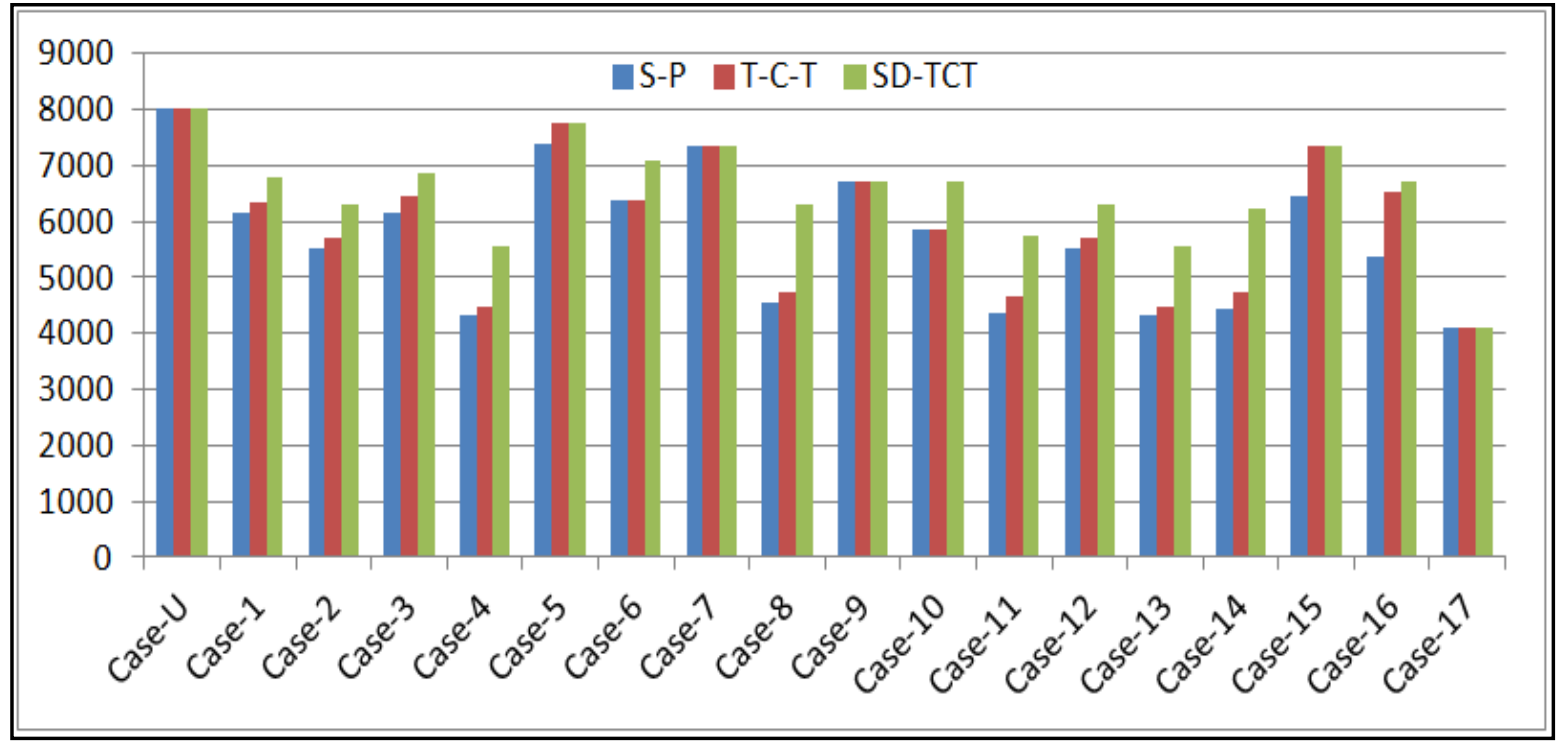

Figure 16. Comparison of GMPP's under different shading cases in $5 \times 6$ array size configurations

\section{CONCLUSIONS}

In order to optimize the solar PV power in a particular shading cases, this work implements a wide shading effect distribution technique across the array size range of $i \times$ $\mathrm{j}(\mathrm{i}=\mathrm{j}$ and $\mathrm{i} \neq \mathrm{j}$, where $\mathrm{i}$ is row number and $\mathrm{j}$ is column number). The physical position of modules for each shading case, without any change in the electric connection, shall only be changed in the proposed method once at the time of the installation. The proposed SD-TCT configuration is cost-effective and easy for implementing a large PV farm in real time, as there are not too many switches and sensors required here. The power provided by SD-TCT is always more than the SP and TCT configuration. 


\section{Conflict of Interest}

The authors declare that there is no conflict of interests regarding the publication of this paper.

\section{REFERENCES}

[1] Roy Chowdhury, S., and Saha, H. (2010). Maximum power point tracking of partially shaded solar photovoltaic arrays. Solar Energy Materials and Solar Cells, 94(9), 1441-1447. DOI: 10.1016/j.solmat.2010.04.011

[2] Kaushika, N. D., and Gautam, N. K. (2003). Energy yield simulations of interconnected solar PV arrays. IEEE Transactions on Energy Conversion, 18(1), 127-134. DOI: 10.1109/TEC.2002.805204

[3] Karatepe, E., Boztepe, M., and Çolak, M. (2007). Development of a suitable model for characterizing photovoltaic arrays with shaded solar cells. Solar Energy, 81(8), 977-992. DOI: 10.1016/j.solener.2006.12.001

[4] Hernández, J., Garcia, O., and Jurado, F. (2012). Photovoltaic devices under partial shading conditions. International Review on Modelling and Simulations, 5, 414425.

[5] Patel, H., and Agarwal, V. (2008). MATLAB-Based Modeling to Study the Effects of Partial Shading on PV Array Characteristics. IEEE Transactions on Energy Conversion, 23(1), 302-310. DOI: 10.1109/TEC.2007.914308

[6] Bidram, A., Davoudi, A., and Balog, R. S. (2012). Control and Circuit Techniques to Mitigate Partial Shading Effects in Photovoltaic Arrays. IEEE Journal of Photovoltaics, 2(4), 532-546. DOI: 10.1109/JPHOTOV.2012.2202879

[7] Vijayalekshmy, S., Rama Iyer, S., and Beevi, B. (2015). Comparative Analysis on the Performance of a Short String of Series-Connected and Parallel-Connected Photovoltaic Array Under Partial Shading. Journal of The Institution of Engineers (India): Series B, 96(3), 217-226. DOI: 10.1007/s40031-014-0143-7

[8] Belhachat, F., and Larbes, C. (2015). Modeling, analysis and comparison of solar photovoltaic array configurations under partial shading conditions. Solar Energy, 120, 399-418. DOI: 10.1016/j.solener.2015.07.039

[9] Wang, Y.-J., and Hsu, P.-C. (2011). An investigation on partial shading of PV modules with different connection configurations of PV cells. Energy, 36(5), 30693078. DOI: 10.1016/j.energy.2011.02.052

[10] BALARAJU, V., and Chengaiah, C. (2020). A Comprehensive Study on Rearrangement of Modules Based TCT Configurations of Partial Shaded PV Array with Shade Dispersion Method. Trends in Renewable Energy, 6, 37-60. DOI: 10.17737/tre.2020.6.1.00111

[11] Rani, B. I., Ilango, G. S., and Nagamani, C. (2013). Enhanced Power Generation From PV Array Under Partial Shading Conditions by Shade Dispersion Using Su 
Do Ku Configuration. IEEE Transactions on sustainable energy, 4(3), 594-601. DOI: 10.1109/TSTE.2012.2230033

[12] Sahu, H. S., Nayak, S. K., and Mishra, S. (2016). Maximizing the Power Generation of a Partially Shaded PV Array. IEEE Journal of Emerging and Selected Topics in Power Electronics, 4(2), 626-637. DOI: 10.1109/JESTPE.2015.2498282

[13] Raju, V.B., and Chengaiah, Ch. (2019). Performance Analysis of Conventional, Hybrid and Optimal PV Array Configurations of Partially Shaded Modules. International Journal of Engineering and Advanced Technology, 9(1), 3061-3073. DOI: 10.35940/ijeat.A1661.109119

[14] Yadav, A. S., Pachauri, R. K., Chauhan, Y. K., Choudhury, S., and Singh, R. (2017). Performance enhancement of partially shaded PV array using novel shade dispersion effect on magic-square puzzle configuration. Solar Energy, 144, 780797. DOI: 10.1016/j.solener.2017.01.011

[15] Kaushika, N. D., and Gautam, N. K. (2003). Energy yield simulations of interconnected solar PV arrays. IEEE Transactions on Energy Conversion, 18(1), 127-134. DOI: 10.1109/TEC.2002.805204

[16] Gautam, N. K., and Kaushika, N. D. (2002). Reliability evaluation of solar photovoltaic arrays. Solar Energy, 72(2), 129-141. DOI: 10.1016/S0038092X(01)00085-8

Article copyright: (C) 2021 V. Bala Raju, Dr. Ch. Chengaiah. This is an open access article distributed under the terms of the Creative Commons Attribution 4.0 International License, which permits unrestricted use and distribution provided the original author and source are credited. 